\title{
Representation in Healthcare Institutions Promotes Intergroup Tolerance: Evidence from the COVID-19 Crises in Israel and the US
}

\author{
Chagai M. Weiss ${ }^{\dagger}$
}

July 22, 2020

\begin{abstract}
How does minority representation in public institutions shape intergroup relations? To answer this question, I develop a theory of prejudice reduction through descriptive representation. I suggest that embedding minorities in public institutions can promote tolerance by providing majority group members with positive information regarding minorities. To test my theory, I implemented a survey experiment in Israel, further replicated in the U.S., during the first outburst of the COVID-19 pandemic. In the experiment, treated respondents were informed about the share of minority (Arab/Muslim) workers in healthcare institutions. Results from Israel suggest that information about minority representation reduces prejudice and promotes preferences for political inclusion in a similar magnitude to about a one-unit leftward-shift on a seven-point ideology scale. Similar, albeit more moderate patterns emerge from the U.S. These findings emphasize how institutions and the people embedded within them can shape intergroup relations.
\end{abstract}

${ }^{\dagger} U W$ - Madison, $\square$ : cmweiss3@wisc . edu, @: www . chagaimweiss . com. This project was pre-registered on OSF: https://osf.io/bmxr4/, and reviewed by UW-Madison IRB:(2020-0381/2020-0499-CP001). I thank Lotem Bassan-Nygate, Rikhil Bhavnani, Yoi Herrera, and Scott Williamson for helpful comments and suggestions. 


\section{Introduction}

How do majority group members respond to minority representation in public institutions? ${ }^{1}$ Existing evidence suggests that descriptive representation in the ranks of institutions-such as police forces, schools, and hospitals-improves public goods provision, satisfaction, trust, and cooperation amongst minorities (Meier 1975; Riccucci, Van Ryzin and Lavena 2014; Nanes 2018; Alsan, Garrick and Graziani 2019). Yet less is known about majority group members' responses to such representation. This gap is consequential since the effects of minority representation may cut both ways. Specifically, representation may engender threat perceptions amongst members of a majority group leading to increased prejudice. Alternatively, representation can foster tolerance resulting in more favorable intergroup relations (Hajnal 2001).

To address this gap, I develop a theory of prejudice reduction through representative institutions. Building on theoretical frameworks in social and political psychology (Wittenbrink, Judd and Park 2001; Blair 2002; Ramasubramanian 2007; Williamson 2019), I suggest that representative institutions provide majority group members with positive information about minorities and their role in society. In turn, this information can reduce prejudice and generate tolerance.

To test my theory, I consider how minority representation in healthcare institutions-a central arena of public goods provision, which in OECD countries accounts for $15 \%$ of government expenditures (OECD 2019)-affects intergroup prejudice and preferences for political inclusion. Specifically, during the initial outbreak of COVID-19, I implemented a nationally representative survey experiment in Israel, which I further replicated in the U.S. In the Israeli (U.S) experiment, I exposed Jewish (non-Muslim) respondents to information regarding the share of Arab (MuslimAmerican) healthcare workers in institutions responding to the COVID-19 crisis. My evidence suggests that information about minority representation in healthcare provision reduces prejudice, and in the Israeli case promotes preferences for political inclusion. Indeed, despite the subtlety of my experimental interventions, effect sizes are substantively significant, and in the Israeli case

\footnotetext{
${ }^{1}$ Throughout this paper I adapt a colloquial understanding of institutions as non-elected organizations that govern, educate, provide for, or organize citizens (Tankard and Paluck 2017).
} 
are equivalent to the effects of approximately a one-unit leftward-shift on a seven-point ideology scale.

I make two contributions to the existing literature. First, building on previous research regarding electoral representation (Mansbridge 1999; Hajnal 2001; Beaman et al. 2009; Chauchard 2014), I consider an unexplored externality of diversity in non-elected institutions. Doing so, I extend recent findings which suggest that diversity has beneficial outcomes for minorities (Alsan, Garrick and Graziani 2019; Nanes 2018; Riccucci, Van Ryzin and Lavena 2014), and I demonstrate how mere information about the share of minority workers in healthcare institutions reduces prejudice and promotes inclusivity amongst majority group members. Second, I contribute to the prejudice reduction literature by adapting an institutional perspective. Doing so, I demonstrate that the identity of agents operating within public institutions affects mass-attitudes, which are oftentimes thought to be deeply ingrained and resistant to change.

\section{Descriptive Representation in Non-Elected Institutions}

Descriptive representation is often closely linked with electoral politics (Pitkin 1967). However, dating back to Kingsley's early explorations of British political institutions (1944), social scientists have emphasized the importance of minority representation in non-elected institutions which provide public goods. Indeed, theoretical frameworks in public policy suggest that descriptive representation in bureaucracies improves public goods provision. Such improvement is theorized to be driven by three central mechanisms relating to: the behavior of minority civil servants, the responses of non-minority civil servants to the presence of minorities in their institutions, and the symbolic effect that representation has on minority clients (Mosher 1968; Rosenbloom and Featherstonhaugh 1977; Riccucci, Van Ryzin and Li 2016).

In line with these theoretical frameworks, scholars have linked descriptively representative public institutions with improved policing (Nanes 2018), enhanced education (Keiser et al. 2002), beneficial health outcomes (Alsan, Garrick and Graziani 2018), organizational efficiency (Rasul and Rogger 2015; Fernandez, Koma and Lee 2018), reduced bias in voter registration processes (Neggers 2018), and more lenient court decisions (Grossman et al. 2016). More so, scholars have 
demonstrated that even when lacking action from a civil servant, information about the mere presence of an underrepresented group within an institution can foster trust, perceived legitimacy, and willingness to coproduce amongst citizens (Karim 2019; Theobald and Haider-Markel 2008; Riccucci, Van Ryzin and Lavena 2014; Riccucci, Van Ryzin and Li 2016).

\section{Can Descriptive Representation Reduce Prejudice?}

While the existing literature has made important advances identifying the effects of descriptive representation on public goods provision, it has yet to consider whether and how such representation shapes intergroup relations. This oversight is rather surprising, as non-elected institutions and the agents within them interact frequently and intimately with citizens (Karim 2020; Pepinsky, Pierskalla and Sacks 2017; Lipsky 1980). To that extent, one may expect that the make-up of public institutions which impact citizens' daily lives may affect intergroup relations.

Studies linking electoral representation with citizens' prejudice and bias provide encouraging evidence to bolster this expectation. Indeed, electoral representation has been theorized to promote tolerance by providing information, positioning minorities in a visible position of power, changing minorities' role within their social network, or facilitating intergroup contact between minority elected officials and constituents (Hajnal 2001; Beaman et al. 2009; Chauchard 2014). Building on this evidence, one may expect that diversity and representation in the ranks of schools, hospitals, police stations, and other institutions providing public goods, will promote tolerance amongst majority group members.

A host of theoretical frameworks in social and political psychology bolster this expectation. First, prejudice is often thought to be driven by limited information (Allport 1954), as well as negative stereotypes about minority group members (Ramasubramanian 2007; Ramasubramanian and Oliver 2007; Burns, Monteith and Parker 2017). Therefore, representation in public institutions can increase majority group members' familiarity with, and knowledge about minorities. Such familiarity and knowledge can reasonably be expected to generate more tolerant attitudes. Indeed, information regarding minority representation may be especially powerful if it counters prevailing stereotypes (Ramasubramanian 2007; Ramasubramanian and Oliver 2007), or corrects 
misperceptions about out-groups (Williamson 2019).

Second, existing research suggest that the social roles in which individuals are embedded, impact how they are evaluated. According to such frameworks, prejudice is rather malleable. Consequentially, contextual features such as an individual's occupation are expected to condition the extent to which they elicit positive or negative reactions from an out-group member (Wittenbrink, Judd and Park 2001; Blair 2002; Barden et al. 2004). To the extent that the social role of a minority in a given institution reinforces perceptions of group variability and provides positive information (Wolsko et al. 2003), such representation could be expected to reduce prejudice towards the minority group as a whole.

Building on these insights, I suggest that representation of minorities in public institutionsespecially when minorities are socially and politically excluded, and institutions are held in highesteem-will reduce prejudice. Thus learning that a minority group member is an integral part of a school, hospital, or appellate court, will motivate majority group members to update their beliefs, and adapt a more complex, or even favorable perspective regarding the qualities of the out-group.

\section{Research Design}

Identifying the effects of descriptive representation in public institutions on mass-prejudice is challenging, since individual- or community-level prejudice may be a cause, rather than an effect of representation. To sidestep this challenge and test my theory of prejudice reduction through descriptive representation, I adapt an experimental approach. Specifically, I focus on the attitudinal effects of information regarding minority representation in healthcare institutions.

As noted above, representation may affect attitudes through a host of mechanisms. However, since my theoretical framework focuses on information, as a central link tying representation with prejudice reduction, I adapt a survey-based experimental empirical approach. This approach allows me to simply compare prejudice rates amongst respondents who are informed or not informed about the share of minorities within public institutions. 


\section{Institutional Focus: Healthcare Provision}

My focus on representation in healthcare institutions is motivated by four reasons. First, healthcare facilities have been explored in the literature on representative bureaucracy and institutional diversity (Gade and Wilkins 2012), and there is evidence to suggest that diversity improves health outcomes for minority clients (Alsan, Garrick and Graziani 2018). Thus, it is important to understand whether diversity and representation have further benefits for intergroup relations.

Second, medical care is a near universal experience. Indeed, most citizens engage with healthcare institutions regardless of their age, partisanship, or ideological preferences. Third, healthcare institutions are a leading sector with regards to minority representation in Israel (Rosner 2016), and in other countries as well (Patel et al. 2018). Indeed, in the Israeli context, given stark patterns of segregation (Enos and Gidron 2018), hospitals and medical clinics serve as a central hub where Jews and Arabs interact. ${ }^{2}$ More so, policy reports suggest that healthcare institutions serve to bridge gaps between minority and majority group members (Rosner 2016).

Lastly, since the outbreak of COVID-19, healthcare institutions and their workers have gained much salience amongst the general public. Indeed, health experts appear regularly on national TV. More so, doctors and nurses are at the spearhead of state responses to local and global health challenges. As demonstrated in a snapshot from a viral information campaign in Israel (Figure 1), ${ }^{3}$ the role of Arabs in combatting COVID-19 has been a salient issue for the Israeli public. Similar campaigns emphasizing the role of immigrants in healthcare institutions were developed in the U.S., ${ }^{4}$ and in the UK prime-minister Boris Johnson gave a dramatic speech alluding to the role of minority-immigrant healthcare workers in saving his life (Booth and Adam 2020).

\footnotetext{
${ }^{2}$ Hospitals in Israel employ a large share of Arab professionals, in relation to other government institutions. More specifically, the share of Arabs employed in the Israeli healthcare system is double that of their general employment rate in the Israeli labor market (Rosner 2016).

${ }^{3}$ This campaign was produced by an Israeli organization named "Have you seen the Horizon Lately?", and can be viewed through the following link: https://www.facebook.com/watch/?v=292639341723781, last checked on July 26, 2020.

${ }^{4}$ See https://twitter.com/Americas Voice/status/1260332332701102080, last checked on June 26, 2020.
} 


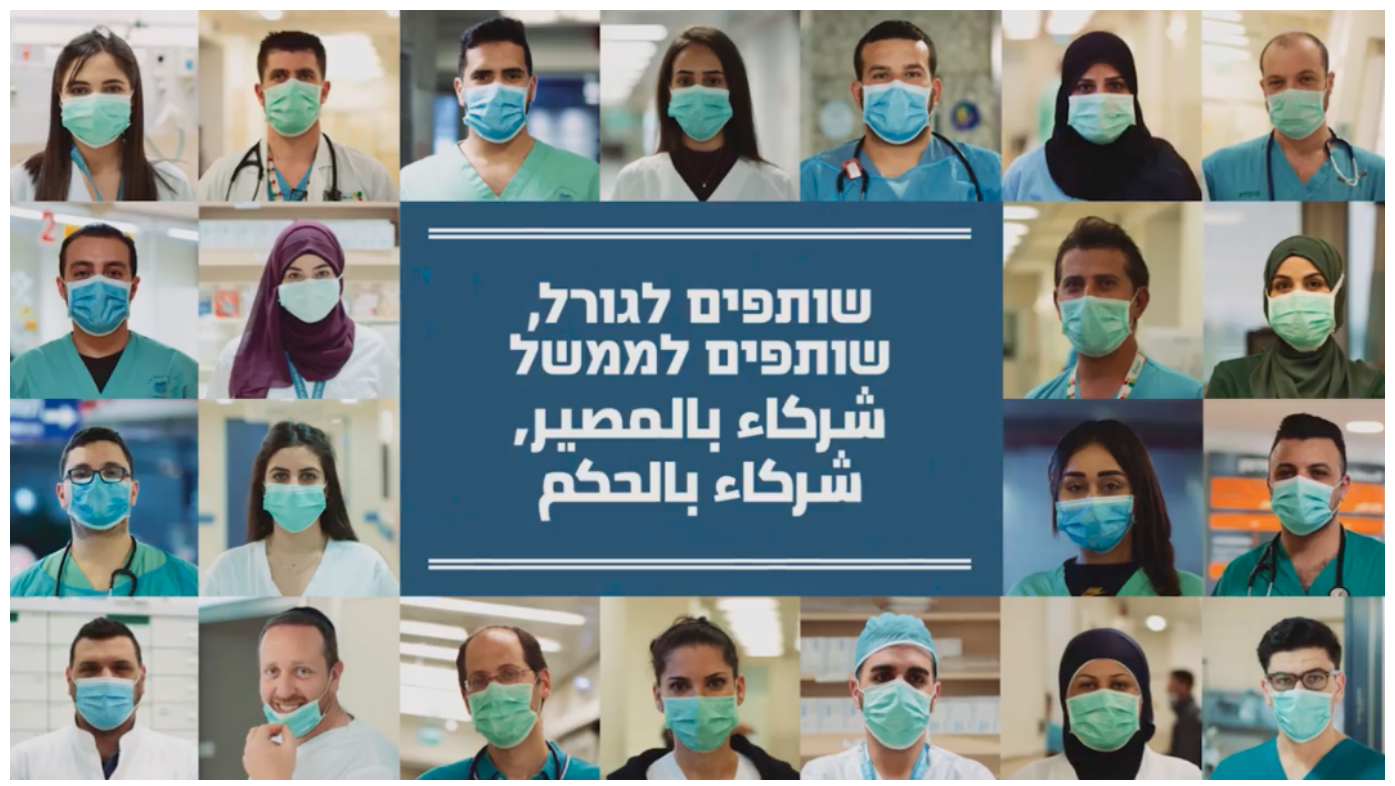

Figure 1: Arab Healthcare Workers Informational Campaign - This is a screenshot from a social media campaign in Israel with over 2,000,000 views. The campaign was titled in Hebrew and Arabic "Partners in Fate, Partners in Governance", and it depicts masked Israeli doctors unveiling their face coverings, revealing their Arab identity, and calling for social change and political inclusion.

In the Israeli context, diversity in healthcare provision has been explicitly linked with a call for more equitable intergroup relations and political arrangements (Hendrix 2020). However one may wonder how Jewish Israelis, and more generally majority group members, react to diversity in healthcare provision, and whether information regarding minority representation in healthcare institutions can reduce prejudice.

\section{Study I: The Effects of Arab Healthcare Workers on Jewish Prejudice}

To test my theory of prejudice reduction through descriptive representation, I implemented a nationally representative survey experiment during the peak of the first COVID-19 outbreak in Israel (see Figure 2 for precise timing). The main goal of the experiment was to determine whether information regarding the share of Arab healthcare workers in Israeli hospitals shapes prejudice and preferences for political inclusion. 


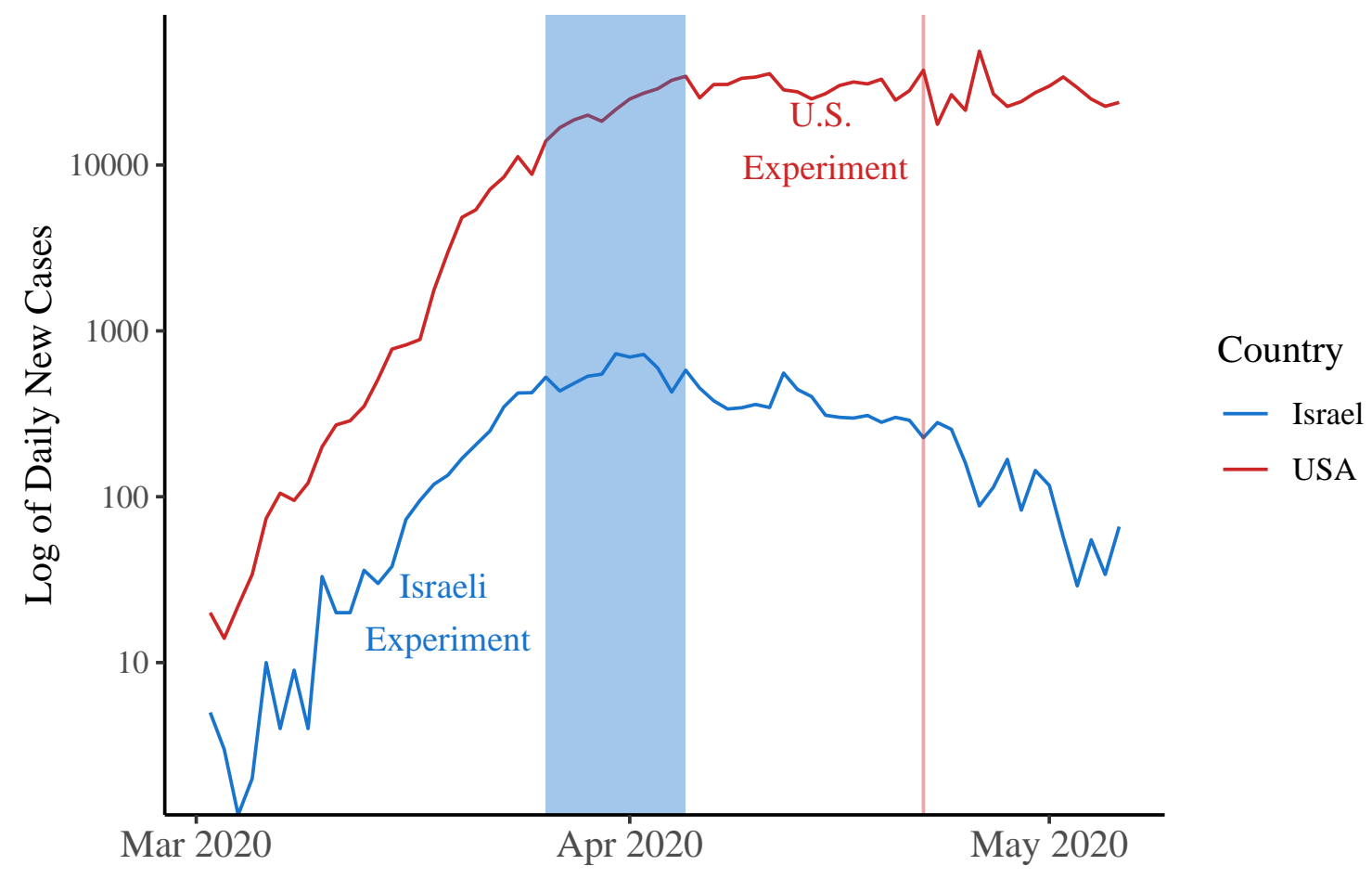

Figure 2: Timeline - This figure presents the log of daily new cases in Israel and in the U.S. Shaded regions represent the timing in which I implemented my original survey experiment in Israel (blue), and replication in the U.S. (red).

\section{Prejudice towards the Arab Minorities in Israel}

Due to its ethnic and religious diversity, Israel is often considered as a unique laboratory for social scientists seeking to better understand intergroup relations (Canetti-Nisim, Ariely and Halperin 2008). Indeed, Israel is entangled in a prolonged intractable conflict with its Palestinian neighbors (Bar-Tal 1998). This conflict complicates intergroup relations between Jews and Arab citizens of Israel, which represent almost $20 \%$ of the Israeli population.

Arab citizens are a marginalized faction of Israeli society. This manifests itself in their low socio-economic standings, and limited participation in many segments of the labor market (Enos and Gidron 2018). Inequality and marginalization of Arabs contribute to the widely documented prejudice that many Jews hold towards Arab citizens in Israel. This prejudice translates into exclusionary behavior, in-group bias, threat perceptions, and discrimination (Enos and Gidron 2018; Shayo and Zussman 2011; Bar and Zussman 2017; Grossman et al. 2016; Smooha 2004; Pedahzur 
and Yishai 1999; Zussman 2013). The stark patterns of prejudice towards Arabs, combined with the central role that Arabs play in Israeli healthcare institutions, warrant Israel as a suitable site for my experiment.

\section{Experimental Design}

To implement my experiment I recruited a representative sample of 1,366 Jewish Israelis from IPanel - Israel's largest opt-in survey platform (For descriptive statistics of my full sample, see Table A1 in the supplementary materials). ${ }^{5}$ As part of my experiment, I presented survey respondents with a brief vignette describing the initial outbreak of the COVID-19 pandemic in Israel. As depicted in Figure 3, my vignette included background information about the emerging pandemic, as well as three experimental treatments resulting in a fully-crossed $2 \times 2 \times 2$ design.

My main treatment informed survey respondents that in Israel - 27\% of doctors, $24 \%$ of nurses, and $47 \%$ of pharmacy workers are Arab citizens and residents of Israel (see blue text in Figure 3). ${ }^{6}$ In addition, I experimentally embedded information regarding Knesset members (MKs) support for political exclusion (see red text in Figure 3), as well as information regarding the severity of the COVID-19 crisis (see green text in Figure 3), in order to determine the extent to which such factors (i.e. elite political exclusion and crisis severity) moderate the effects of minority descriptive representation on prejudice. In doing so, I follow recent experimental studies of prejudice (Broockman and Kalla 2016; Williamson 2019; Kalla and Broockman 2020), and consider the possibility that competitive information environments might dampen (or reinforce) my main effects.

After reading the experimental vignette, respondents where presented with several batteries of political and social questions, including five main outcomes of interest, measuring: i) intergroup affect, ii) preferences for social exclusion, iii) intergroup trust, iv) attitudes about intergroup peace, and v) preferences for political inclusion. These outcomes have been used in recent research on

\footnotetext{
${ }^{5}$ IPanel provides researches access to a representative sample of Israeli internet users with regards to gender, age, religiosity, education, and geographical area. More so, it is commonly used for social scientific research (e.g. Grossman, Manekin and Miodownik 2015; Grossman, Manekin and Margalit 2018).

${ }^{6}$ This information is based on official statistics reported in Haaretz during the time of my intervention (Yaron 2020).
} 


\section{Please read the following paragraphs carefully:}

In the past weeks the Coronavirus reached most countries around the world and created both health and economic crises. Officials in the Ministry of Health consider the virus to be a serious crisis which will have unprecedented adverse effects on public health and the economy in Israel. They expect the crisis to have real negative consequences on Israeli public health, and for that reason it is very important that Israeli healthcare systems prepare to deal with the consequences of the virus which does not have any treatment yet.

According to the Ministry of Health, the virus's main symptoms are:

- Fever

- Cough

- Sore throat

- Respiratory issues

According to official statistics from the Ministry of Health and the Central Bureau of Statistics, there are tens of thousands of Israeli citizens that work in health care system. $20.8 \%$ of healthcare workers in Israel are Arab. Specifically, 27\% of doctors, $24 \%$ of nurses, and $47 \%$ of pharmacy workers are Israeli-Arab citizens.

In recent days, many MKs expressed their gratitude to all healthcare workers that are working around the clock in order to provide medical care for all Israeli citizens, and stated that they are eager to serve the public through intense work in the Knesset's committees. In addition, some MKs expressed their support in the political developments leading towards an emergency government / Jewish-Zionist emergency government which does not include the Joint Arab List. These MKs stated that it is not suitable to have members of the Joint Arab List leading the country.

Figure 3: Experimental Vignette: 2x2x2 Design. My main treatment regarding Arab representation in healthcare institutions is depicted in blue. My additional severity and exclusion treatments are depicted in green and red sucessively. 
intergroup relations in Israel (Samooha 2013). More so, my measure of preferences for social exclusion (often referred to as a social distance scale), has been shown to be a potent determinant of Jewish respondents' discriminatory behaviors towards Arabs (Enos and Gidron 2018).

Recent methodological examinations of attitudinal responses to survey items and experiments suggest that demand effects and social desirability are unlikely to bias my main estimates. Indeed, comparisons of direct and indirect attitudinal measures of prejudice show that the extent to which survey respondents censor their self-reported prejudicial attitudes is limited (Blair, Coppock and Moor Forthcoming). More so, recent explorations of demand effects in survey experiments suggest that even incentivizing respondents' to confirm researchers' explicitly stated hypotheses, does not produce demand effects (Mummolo and Peterson 2019). However, to further mitigate such concerns, I embedded questions about prejudice towards Arabs within more general batteries regarding attitudes towards multiple social groups in Israel (i.e. right- and left-wing partisans). I present the wording of questions employed as my main outcomes in Table 1, and provide an elaborate description of my full survey in Section A.1 of my supplementary materials.

\section{Estimation Strategy}

Random assignment of respondents to treatment conditions allows for a simple estimation strategy, since in expectation treatment and control groups should be well balanced on all observable and unobservable social and demographic covariates. ${ }^{7}$ For this reason, in my main analyses I adapt a pre-registered bivariate OLS model in which each prejudice related outcome, is regressed over my main treatment (Arab representation). However, due to a small (albeit statistically significant) gender difference between respondents assigned to my main treatment and control conditions, in section A1 of the appendix I provide additional results controlling for pre-treatment covariates, as well as additional treatment arms. Doing so, does not impact my findings.

\footnotetext{
${ }^{7}$ In Table A3 of the appendix, I present balance tests for a set of central covariates (age, gender, education, ethnicity, and ideology).
} 
Table 1: Outcome Measures for Israel and U.S. Experiments

\begin{tabular}{|c|c|c|c|}
\hline Item & $\begin{array}{c}\text { Question } \\
\text { Israeli Study }\end{array}$ & $\begin{array}{l}\text { Question } \\
\text { U.S Study }\end{array}$ & $\begin{array}{c}\text { Possible } \\
\text { Responses }\end{array}$ \\
\hline $\begin{array}{c}\text { Feeling } \\
\text { Thermometer }\end{array}$ & $\begin{array}{c}\text { Please place the following } \\
\text { social groups on a feeling } \\
\text { thermometer (Left Wing Supporters / } \\
\text { Right Wing Supporters / Arabs) }\end{array}$ & $\begin{array}{l}\text { Please place the following social } \\
\text { groups on a feeling thermometer } \\
\text { (Democrats / Republicans / Hispanics / } \\
\text { Muslims / African Americans / Asians) }\end{array}$ & 1-100 Scale \\
\hline $\begin{array}{c}\text { Social } \\
\text { Distance }\end{array}$ & $\begin{array}{l}\text { What is the closest level of } \\
\text { proximity which you would accept } \\
\text { with (Left Wing Supporters / } \\
\text { Left Wing Supporters / Arabs) }\end{array}$ & $\begin{array}{c}\text { What is the closest level of } \\
\text { proximity which you would } \\
\text { accept with (Democrats / Republicans / } \\
\text { Hispanics / Muslims / African } \\
\text { Americans / Asians) }\end{array}$ & $\begin{array}{l}\text { 1. Not accept in my country } \\
\text { 2. Accept as guest in my country } \\
\text { 3. Accept as citizen in my country } \\
\text { 4. Accept as co-worker } \\
\text { 5. Accept as neighbor } \\
\text { 6. Accept as close friend } \\
\text { 7. Accept as family through marriage }\end{array}$ \\
\hline Peace & $\begin{array}{c}\text { Do you agree with the following } \\
\text { statement? "Most Arabs want to } \\
\text { live in peace" }\end{array}$ & $\begin{array}{l}\text { Do you agree with the following } \\
\text { statement? "Most Muslims in } \\
\text { the U.S. want to live in peace" }\end{array}$ & 1:7 Disagree - Agree Scale \\
\hline Trust & $\begin{array}{c}\text { Do you agree with the following } \\
\text { statement? "Most Arabs in Israel } \\
\text { can be trusted" }\end{array}$ & $\begin{array}{l}\text { Do you agree with the following } \\
\text { statement? "Most Muslims in } \\
\text { the U.S. can be trusted" }\end{array}$ & 1:7 Disagree - Agree Scale \\
\hline $\begin{array}{l}\text { Political } \\
\text { Inclusion }\end{array}$ & $\begin{array}{c}\text { Do you agree with the following } \\
\text { statement? "Arab MKs should lead } \\
\text { Knesset committees" }\end{array}$ & $\begin{array}{c}\text { Do you agree with the following } \\
\text { statement? "Muslim elected officials } \\
\text { should be leading congressional } \\
\text { committees" }\end{array}$ & 1:7 Disagree - Agree Scale \\
\hline
\end{tabular}




\section{Results}

In Figure 4 I report the average treatment effects of information regarding Arab representation in Israeli healthcare provision on five different attitudinal measures. Positive point estimates resemble a move towards more tolerant and inclusionary attitudes, and for ease of interpretation I standardize all outcomes ( $\mu=0$ and $\sigma^{2}=1$ ). In line with my pre-registered theoretical expectation, Jewish Israelis who learn about the role of Arabs in Israeli healthcare institutions report more tolerant attitudes. Specifically, effect sizes range between almost a quarter and a fifteenth of a standard deviation.

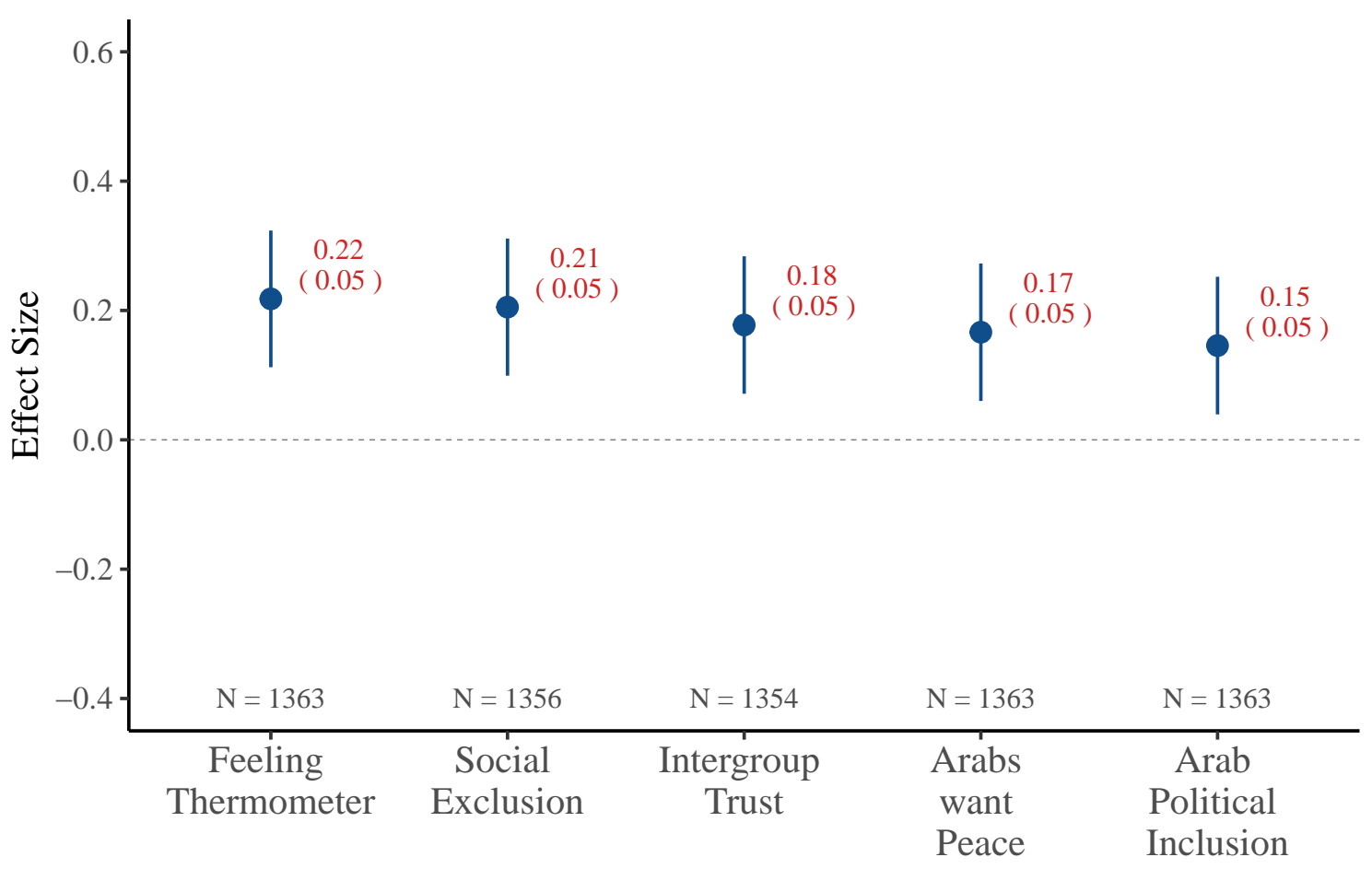

Figure 4: Information about Arab healthcare workers reduces prejudice amongst Jewish Israelis - OLS point estimates and their corresponding confidence intervals represent the average treatment effect of information regarding representation on prejudice attitudes and preferences for political exclusion.

Substantively, the average treatment effect of information regarding Arab representation on Jewish respondents affect towards Arabs (measured through a feeling thermometer) is equivalent to the impact of close to a one unit leftward shift on a seven-point ideology scale. Effect magnitudes 
for all other outcomes are slightly smaller, but are larger than the impact of a half-unit leftward shift on a seven-point ideology scale. These effects are substantively significant, as ideology accounts for a quarter of the variation in preferences for Arab social exclusion. ${ }^{8}$ More generally, these effects are remarkable given the subtle nature of my informational treatment, the deeply rooted nature of prejudice amongst many Israelis (Bar-Tal 1998), the hostile environment towards Arab inclusion during my intervention, and the strong links between symbolic prejudicial attitudes and discriminatory behaviors (Enos and Gidron 2018).

Most notable from Figure 4 is that the effects of information regarding Arab representation in Israeli healthcare institutions, shapes not only symbolic prejudicial attitudes, but also political preferences. Indeed, respondents in the treatment condition are more accepting of the idea that Knesset committees will be led by Arab MKs from the Joint Arab List. This is remarkable given the delegitimization of Arab politicians by mainstream center-left and right-wing politicians, who have referred to Arab MKs in the past as terrorists in suits, or other derogatory names (Zeitoun and Brot 2020; Jaffe-Hoffman 2020).

\section{Does Ideology Moderate Identified Effects?}

The evidence above suggests that providing Israelis with information about Arab representation in healthcare institutions shapes prejudice and preferences for political inclusion. However, one may wonder whether these effects are moderated by respondents partisan ideology - a variable which accounts for more than a quarter of the variation in preferences for Arab social exclusion. Put differently, given the strong link between respondents' partisan ideology and prejudicial outcomes, one may expect that identified effects are largely driven by positive reactions from less-prejudiced left-wingers, and that right-wing respondents react differently, and perhaps in a hostile fashion, to information regarding Arab representation in Israeli healthcare institutions. Such an expectation is quite plausible given recent evidence regarding partisan polarization in Israel (Tsfati and Nir 2017; Bassan-Nygate and Weiss 2020). Alternatively, it is possible that information about repre-

\footnotetext{
${ }^{8}$ When regressing my social exclusion measure over responses to a seven-point ideology scale, the regression $R^{2}=0.27$.
} 
sentation is only effective amongst those holding very exclusionary attitudes (Williamson 2019), whereas more tolerant individuals may not be sensitive to information regarding representation due to ceiling effects.

I consider the possibility of heterogenous treatment effects conditional on partisan ideology in Table 2, by interacting my representation treatment with a 7-point ideology scale. Since ideology correlates with a host of individual level characteristics, I further control for a set of pre-treatment covariates, including: age, gender, ethnicity, religiosity, locality of origin, and education. To increase efficiency I further account for my two other treatment arms relating to the severity of the COVID-19 crisis, and politicians' support for political exclusion.

Across all outcomes, I do not find support for any moderating effect of ideology on my treatment. Indeed, the point estimates of my interaction effect (Representation*Ideology) are both substantively small, and statistically insignificant. In Tables A7-A10 of the appendix, I demonstrate that this result holds across several other specification, including a fully saturated model, and models which focus on "strong" partisans.

These null findings suggest that both right- and left-wing respondents react similarly to information regarding diversity in healthcare provision. More generally, this result is insightful and surprising in light of recent research which documents heightened levels of partisan polarization in Israel (Bassan-Nygate and Weiss 2020). Despite such polarization - both left- and right-wing supporters report more tolerant attitudes when informed of Arab representation in Israeli healthcare institutions.

\section{Additional Analyses and Robustness Checks}

In the appendix, I further consider the moderating effects of my two additional treatment arms relating to the severity of the COVID-19 pandemic, and Israeli politicians exclusionary statements. My pre-registered expectation was that respondents' who are exposed to information that emphasizes the severity of the COVID-19 crises would report higher degrees of prejudice reduction. This is since I expected the severity of the crises to emphasize the importance and contribution of minority healthcare workers. In contrast, building on recent findings regarding the dampening effects 
Table 2: Heterogenous Treatment Effect of Arab Representation Conditional on Ideology

\begin{tabular}{lccccc}
\hline \hline & Therm & SD & Trust & Peace & Pol Inc \\
& $(1)$ & $(2)$ & $(3)$ & $(4)$ & $(5)$ \\
\hline Representation & 0.201 & 0.143 & 0.168 & 0.215 & 0.042 \\
& $(0.100)$ & $(0.095)$ & $(0.098)$ & $(0.099)$ & $(0.087)$ \\
Ideology & 0.251 & 0.267 & 0.287 & 0.281 & 0.316 \\
& $(0.022)$ & $(0.021)$ & $(0.022)$ & $(0.022)$ & $(0.019)$ \\
Representation*Ideology & 0.005 & 0.027 & 0.006 & -0.013 & 0.037 \\
& $(0.029)$ & $(0.028)$ & $(0.029)$ & $(0.029)$ & $(0.026)$ \\
Controls & Yes & Yes & Yes & Yes & Yes \\
$N$ & 1,362 & 1,355 & 1,353 & 1,353 & 1,353 \\
\hline \hline
\end{tabular}

Notes: $\quad$ Controls include: age, gender, ethnicity, religiosity, education, and indicators for exclusion and severity treatments.

of competing informational environments (Williamson 2019), I expected exclusionary statements to attenuate prejudice reduction, as such statements provide institutional legitimacy for intolerant attitudes. Nonetheless, as depicted in Tables A4-A5 in the appendix, I do not find support for these expectations. ${ }^{9}$

In section A.2 of the appendix I demonstrate the stability of my results to a host of alternative specifications in which I control for an unbalanced covariate (gender), as well as additional treatment arms. I also demonstrate that respondents' age, which in the context of COVID-19 proxies vulnerability and medical risk, does not moderate treatment effects (Table A6). Lastly, in Figure A2 of the appendix, I consider a placebo test in which I demonstrate that my treatment does not have significant effects on attitudes towards other social groups (i.e. left and right-wing partisans). This finding emphasizes that information about Arab representation facilitates groupspecific updating, rather than a general turn towards more positive evaluations of social groups. Together, these additional analyses further strengthen my confidence in the identified effects of my

\footnotetext{
${ }^{9}$ I present several manipulation checks which suggest that unlike the diversity and severity treatments, my exclusion treatment was not effective in shifting respondents' perceptions regarding political elites' preferences for exclusion. Therefore, as I further discuss in section A.2 of the appendix, the null moderating effect of exclusion is likely driven by the limited effectiveness of this specific treatment arm.
} 
first experiment, which provide strong support in favor of my theory of prejudice reduction through descriptive representation.

\section{Study II: The Effects of Muslim Healthcare Workers on Non-Muslim American Prejudice}

Thus far I have provided evidence in support of my theory from Israel - An important case for scholars of prejudice reduction (Canetti-Nisim, Ariely and Halperin 2008). However, it is unclear whether such evidence generalizes to additional contexts. Since generalizability is primarily achieved through replication of similar studies in different sites (McDermott 2011), I now turn to test my theory in an alternative case - The U.S.

\section{Prejudice towards Muslims in the U.S.}

Like in Israel, where intergroup relations are shaped by a host of ethnic, religious, and partisan cleavages (Canetti-Nisim, Ariely and Halperin 2008; Enos and Gidron 2016, 2018; Bassan-Nygate and Weiss 2020), multiple minority groups in American society suffer from negative stereotypes and prejudice (Sides and Gross 2013; Williamson 2019; Lajevardi Forthcoming). However, in my U.S. study, I focus on Muslim representation in healthcare provision and its effects on majority group attitudes towards Muslim Americans. ${ }^{10}$ My focus on the U.S., and specifically on prejudice towards Muslims, is informed by four similarities linking the American context with Israel.

First, previous studies suggest that like Arab doctors in Israel, Muslim physicians are an integral part of U.S. healthcare institutions. Indeed, though Muslims comprise only $1 \%$ of the American population, estimates suggest that $5 \%$ of all U.S. physicians are Muslim (Padela et al. 2016). Second, despite the over-representation of Muslims in healthcare institutions relative to their size in the American population (like in the Israeli context), Muslim Americans still suffer from a great deal of negative stereotypes and prejudice (Sides and Gross 2013; Williamson 2019; Lajevardi and Abrajano 2019; Lajevardi Forthcoming). Indeed, some accounts suggest that Muslims are one of the social groups suffering most severely from hostile attitudes in the U.S. (Kalkan, Layman and

\footnotetext{
${ }^{10}$ Given recent findings which demonstrate that Americans draw little distinctions between "Muslims", and "Muslim-Americans" - I use both terms interchangeably to refer to Muslims residing in the U.S.
} 
Uslaner 2009). Similarly other scholars emphasize that "Prejudice appears to be alive and well with respect to Muslims..." and that most Americans are unlikely to view Muslims as anything other than enemies (Sides and Gross 2013). Such grim accounts emphasize the challenge and importance entailed in studying institutional approaches for prejudice reduction towards Muslims in the U.S.

Third, like prejudice towards Arabs in Israel, prejudice towards Muslims in the U.S. is linked with stereotypes relating to violence, (lack of) trustworthiness, and security threats. More so, such negative stereotypes and attitudes have been identified as a cause of support for exclusionary politicians and policies (Sides and Gross 2013; Lajevardi and Abrajano 2019). Lastly, in a similar manner to the Israeli case, negative sentiments towards Muslims is not confined to mass-public opinion. Indeed, such sentiment manifests in a host of exclusionary policies relating to immigration bans, and proposed attempts to surveil mosques, and keep updated registries of Muslim U.S. residents for security purposes (Lajevardi and Abrajano 2019).

Despite these similarities, three important structural factors differentiate between Israel and the U.S., warranting my additional empirical tests noteworthy. First, the relative share of Muslims in the U.S. population, and the proportion of Muslim physicians in American healthcare institutions is substantially smaller than in Israel. These differences allow for consideration of the effectiveness of representation in shaping intergroup relations, in an instance where the minority group is smaller (i.e. $1 \%$ rather than $20 \%$ ), and its relative role within institutions is more modest (i.e. $5 \%$ rather that $20 \%)$.

Second, American Muslims differ from Arabs in Israel, in that they are for the most part either immigrants or descendants of immigrants. More so, Muslim Americans are far more ethnically diverse (Lajevardi and Abrajano 2019), when compared with Arabs in Israel. Therefore, by focusing on prejudice in the U.S., I am able to determine the extent to which representation is effective in reducing prejudice towards a far more heterogenous social group.

Lastly, unlike the Israeli case, the U.S. is not embedded in an ongoing intractable conflict (Bar-Tal 1998). More so, unlike many Arabs in Israel which have Palestinian national aspirations, 
Muslim Americans do not have distinct national aspirations. Therefore, by turning to the U.S., I am able to consider the extent to which identified effects generalize to ethnically diverse societies which are not entangled in an ongoing national conflict.

Clearly, there are some stark similarities, as well as notable differences between both of my empirical cases. Since cross-site differences cannot be reduced to one variable, attributing contextual moderation in effects to one factor alone would not be credible - and doing so is not the objective of my replication. However, by turning to the U.S., and examining the replicability of my findings in a different context, I seek to bolster the credibility of my theory, and provide evidence for its generalizability beyond Israel.

\section{Experimental Design}

I fielded my second experiment through Lucid, amongst a representative sample of 1,216 U.S. survey respondents (See figure 2 for precise timing). ${ }^{11}$ After filling out a battery of pre-treatment demographics, respondents were exposed to a fully crossed $2 \times 2 \times 2$ experimental vignette which described the crisis around the COVID-19 pandemic in the U.S. As depicted in the appendix (Figure A3), this vignette was very similar to the one I previously employed in the Israeli context.

Specifically, my main treatment informed respondents that in many localities there is a sizable proportion of Muslim healthcare workers, and that more generally there are over 50,000 Muslim doctors and many more nurses working in American hospitals. These statistics were based on previous studies of diversity in American healthcare institutions (Abu-Ras, Laird and Sensai 2012; Padela et al. 2016). ${ }^{12}$ In addition, like in the Israeli experiment, I embedded treatments regarding political elite's active support for exclusion (alluding to Muslim immigration bans), as well as

\footnotetext{
${ }^{11}$ Lucid is a platform which provides access to online survey respondents. Recent research demonstrates the suitability of the Lucid platform for evaluating social scientific theories (Coppock and McClellan 2019).

${ }^{12}$ One notable difference between the treatment in the Israeli and U.S. studies relates to the type of statistics provided. Whereas in the Israeli case I was able to provide official numbers regarding Arab doctors, nurses, and pharmacists, to the best of my knowledge such statistics regarding Muslim healthcare workers do not exist in the U.S. Therefore, in my U.S. experiment I rely on more general estimations from recent policy reports (Abu-Ras, Laird and Sensai 2012).
} 
information regarding the severity of the COVID-19 crisis. $^{13}$

After reading the vignette respondents were presented with several batteries of questions regarding the extent to which they follow social distancing guidelines, as well as their social and political attitudes and preferences. Most importantly, these batteries included the five outcome measures explored in the Israeli experiment. The precise wording of questions used as outcome measures is depicted in Table 1. ${ }^{14}$

\section{Estimation Strategy}

I follow similar estimation procedures when analyzing data from the U.S. Specifically, in my main analyses I regress five measures of intergroup attitudes over my main treatment to identify the effects of information regarding Muslim representation in healthcare provision. In Figure A4 of the appendix, I demonstrate the robustness of my results to the inclusion of pre-treatment covariates, as well as my additional treatment arms relating to the severity of COVID-19, and politicians preferences for Muslim Exclusion.

\section{Results}

In Figure 5 I report the main effects from my U.S. experiment. As indicated by the positive point estimates, information regarding Muslim representation in U.S. healthcare institutions promotes more tolerance. However, such information does not appear to have a statistically significant effect on preferences for political inclusion.

Notably, the effects of information regarding minority representation are smaller in the U.S.

\footnotetext{
${ }^{13}$ Due to the slight imbalance in gender across treated and controlled groups in the Israeli experiment, I implemented a simple block randomization procedure in the U.S. experiment. Specifically, I block randomized subjects by partisanship (Democrat, Republican, Independent, Other) and gender (Male, Female, Other), resulting in 12 cells in which randomization occurred.

${ }^{14}$ Recent advances in American politics have developed unique indices to study attitudes towards Muslims in the U.S. (Lajevardi and Abrajano 2019; Lajevardi Forthcoming). However, in order to enable a simple and more direct comparison between the the Israeli and U.S. experiments, I employ common survey questions relating to: i) intergroup affect, ii) preferences for social exclusion, iii) intergroup trust, iv) attitudes about intergroup peace, and v) preferences for political inclusion. These measures have been used widely by social scientists across different contexts in order to capture majority group members' prejudice towards minorities.
} 


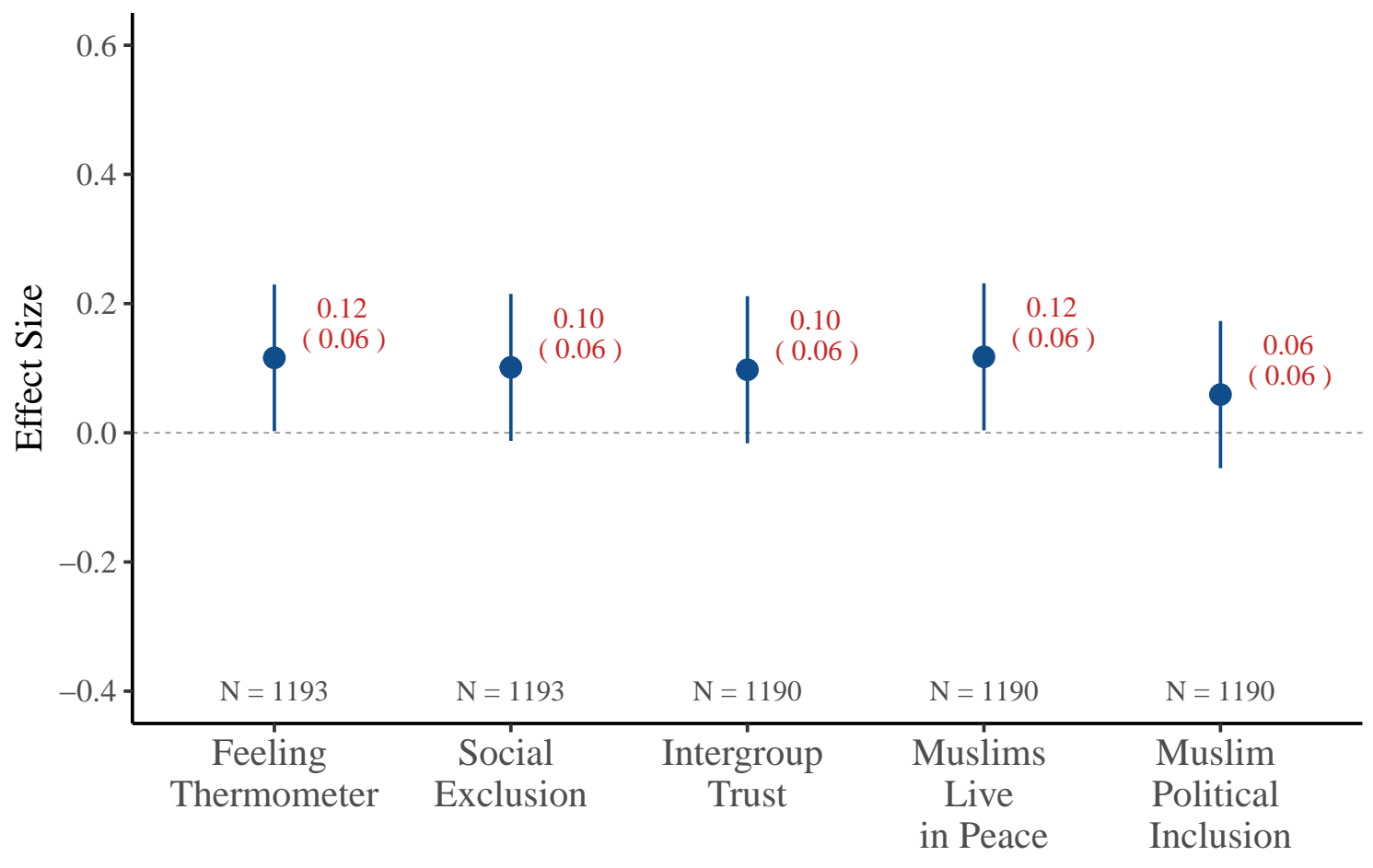

Figure 5: Information about Muslim healthcare workers reduces prejudice amongst nonMuslim Americans - OLS point estimates and their corresponding confidence intervals represent the average treatment effect of information regarding Muslim representation on prejudice attitudes and preferences for social exclusion.

context, when compared with Israel. Indeed, treated respondents who learn about the role of Muslim doctors and nurses in American healthcare institutions, report slightly more than a tenth of a standard deviation increase in affect towards Muslims (measured through a commonly used feeling thermometer), as opposed to almost a quarter of a standard deviation increase in the Israeli case. Substantively, the magnitude of treatment effects amongst my U.S. sample, is equivalent to over two-thirds of the impact of shifting from strong to moderate Republican views.

What might explain the smaller effect size in the U.S. experiment, when compared with results from Israel? One explanation could relate to the varying strength of treatments across both studies. Specifically, the Israeli treatment provided more explicit information regarding the precise share of doctors, nurses, and pharmacists in Israeli healthcare institutions, as opposed to the U.S. treatment which provided more general information regarding Muslim representation. It is possible that this 
variation which was necessitated by the lack of formal statistics on Muslim representation in U.S. healthcare institutions, accounts for variation in effect sizes across both studies.

Alternatively, variation in effect sizes might relate to baseline attitudes towards minorities in both contexts. Specifically, when considering feeling thermometers in both contexts, it appears that hostility towards Arabs is substantially more severe in Israel, than hostility towards Muslims in the U.S (See Figure 6). Indeed, the average of my intergroup affect measure in Israel is 42.4 $\left(\sigma^{2}=24.5\right)$, whereas the identical measure in the U.S. equals $58.4\left(\sigma^{2}=29.9\right)$. Similarly, the Israeli average on my political inclusion variable is almost a full unit lower $\left(\mu=3.5, \sigma^{2}=1.9\right)$ than in the U.S. $\left(\mu=4.4, \sigma^{2}=1.7\right)$. Therefore, it is possible that there is much more "room" to move Israelis with regards to prejudice towards minorities, when compared with American survey respondents. The said, despite the smaller effect sizes, it still appears that American respondents who learn about the share of Muslim doctors and nurses in U.S. healthcare institutions report more tolerant attitudes.
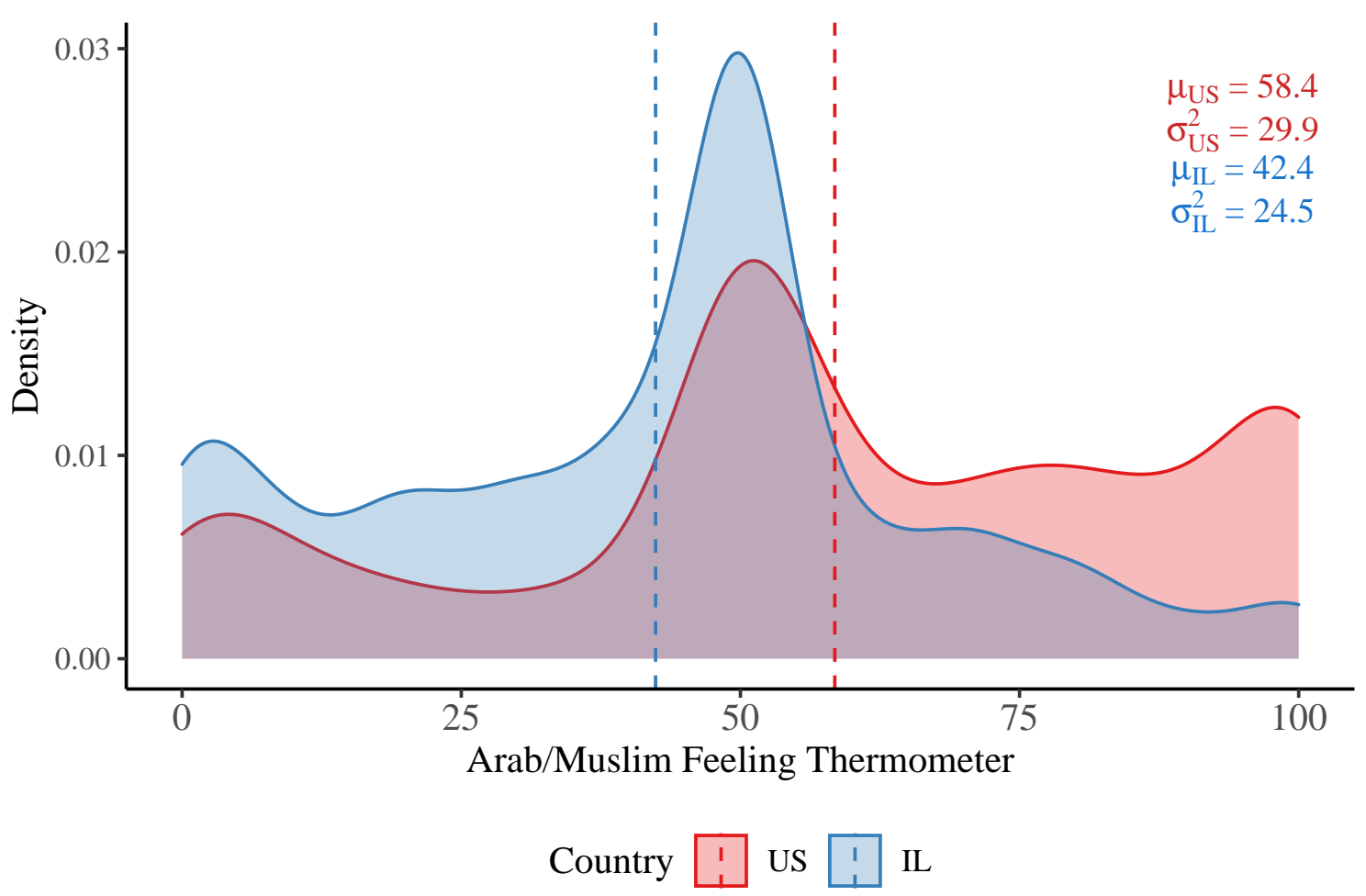

Figure 6: Comparison of Intergroup Affect in Israel and the U.S. - Dotted lines denote country means. 


\section{Does Partisanship Moderate Identified Effects?}

Given the centrality of partisan polarization in the U.S. (Iyengar et al. 2019), one may expect that identified treatment effects vary significantly by partisanship. Specifically, one may worry that information regarding representation reduces prejudice amongst Democrats and independents, but result in backlash effects amongst Republicans. Alternatively, it is possible that Republicans that are on average more prejudicial towards Muslims, will report higher degrees of prejudice reduction, as suggested to some extent by Williamson (2019). I consider these possibilities in Tables 3-4 below.

Specifically, to consider the possibility of polarized reactions to information regarding Muslim representation in U.S. healthcare institutions, I interact my main treatment with a partisanship indicator. To account for pre-treatment covariates which correlate with partisanship, I further control for a set of covariates, including: respondents' race, religiosity, education, age, and experimental block. ${ }^{15}$ To improve the efficiency of my model I further control for other treatment arms. Table 3 (4) compares the effect of my treatment conditional on Democratic (Republican) party identification.

Table 3: Heterogenous Treatment Effect of Muslim Representation Conditional on Party ID Democrats (US)

\begin{tabular}{lccccc}
\hline \hline & Therm & SD & Trust & Peace & Pol Inc \\
& $(1)$ & $(2)$ & $(3)$ & $(4)$ & $(5)$ \\
\hline Representation & 0.091 & 0.123 & 0.129 & 0.196 & 0.058 \\
& $(0.071)$ & $(0.071)$ & $(0.071)$ & $(0.070)$ & $(0.068)$ \\
Democrat & 0.192 & 0.108 & 0.504 & 0.598 & 0.483 \\
& $(0.225)$ & $(0.228)$ & $(0.226)$ & $(0.224)$ & $(0.218)$ \\
Representation*Democrat & 0.071 & -0.051 & -0.069 & -0.192 & -0.004 \\
& $(0.117)$ & $(0.116)$ & $(0.115)$ & $(0.114)$ & $(0.111)$ \\
Controls & Yes & Yes & Yes & Yes & Yes \\
$N$ & 1,192 & 1,187 & 1,185 & 1,185 & 1,185 \\
\hline \hline
\end{tabular}

Notes:

Controls include: age, race, religion, education, block, and indicators for exclusion and severity treatments.

${ }^{15}$ Block randomization was administered according to gender and partisanship. 
Table 4: Heterogenous Treatment Effect of Muslim Representation Conditional on Party ID Republicans (US)

\begin{tabular}{lccccc}
\hline \hline & Therm & Soc Exclusion & Trust & Peace & Pol Inc \\
& $(1)$ & $(2)$ & $(3)$ & $(4)$ & $(5)$ \\
\hline Representation & 0.081 & 0.054 & 0.027 & 0.050 & 0.023 \\
& $(0.069)$ & $(0.069)$ & $(0.068)$ & $(0.067)$ & $(0.066)$ \\
Republican & -0.499 & -0.411 & -0.591 & -0.656 & -0.793 \\
& $(0.118)$ & $(0.117)$ & $(0.117)$ & $(0.115)$ & $(0.113)$ \\
Representation*Republican & 0.110 & 0.151 & 0.228 & 0.223 & 0.101 \\
& $(0.119)$ & $(0.118)$ & $(0.117)$ & $(0.116)$ & $(0.113)$ \\
Controls & Yes & Yes & Yes & Yes & Yes \\
$N$ & 1,192 & 1,187 & 1,185 & 1,185 & 1,185 \\
\hline \hline
\end{tabular}

Notes: Controls include: age, race, religion, education, block, and indicators for exclusion and severity treatments.

For the most part, these additional analyses do not provide support for the expectation that Republicans and Democrats react differently to information regarding Muslim representation in healthcare institutions. Indeed, in nine out of ten models in Tables 3-4, the interaction term Muslim Representation*Republican/Democrat is statistically insignificant. Only in two model (Model 3-4, Table 4) does this interaction approach conventional levels of statistical significance $(p<0.1)$. In Tables A19-A20 of the appendix, I demonstrate that this pattern of limited polarization in treatment effects remains stable when focusing only on strongly identifying Democrats and Republicans. I construe this as evidence for the uniform effect of representation on intergroup attitudes.

\section{Additional Analyses and Robustness Checks}

In Section B.2.3 of the appendix, I consider a battery of additional pre-registered heterogenous treatment effects. First, I explore the possibility that my severity and political exclusion treatments moderate Muslim representation treatment effects. However, like in the Israeli context I find limited support for such moderation. To further consider the possibility that the severity of the COVID-19 crisis moderates my main effects, I leverage two pre-treatment covariates: age, and pre-existing medical conditions. These variables take a value of 1 for respondents who are more vulnerable to COVID-19 due to their age (65+), or medical condition. In Tables A17-A6 
of the appendix, I report interaction models which provide further support for my finding that the severity of the crisis does not moderate the main effects of representation on prejudice.

In Figure A4 of the the appendix, I demonstrate the robustness of my results to additional model specifications where I control for pre-treatment covariates and additional treatment arms. In addition, like in my Israeli study, I implement a placebo test, in which I consider the extent to which information regarding Muslim representation in healthcare institutions shapes attitudes

towards other social groups (Figure A5). Specifically, I focus on attitudes towards Democrats, Republicans, Asian Americans, African Americans, and Hispanics.

For the most part, it appears that other than shaping attitudes towards Muslims, my treatment does not impact attitudes towards other social groups in a consistent fashion. This finding further strengthens my theoretical argument, that representation provides respondents with novel information about Muslims per se. This information in turn, is sufficiently meaningful for respondents to update their attitudes towards the specific minority group represented within the institution under investigation.

Lastly, one may worry that prejudice reduction caused by minority representation in public institutions, might come at the cost of majority group members' willingness to follow guidelines put forward by those institutions. In Table A14 of the appendix, I attempt to address these concerns, by considering the extent to which Muslim representation in healthcare institutions affects citizens' adherence to public health guidelines aimed to limit the spread of COVID-19. Encouragingly, I do not find support for this concern in my additional analyses. Indeed, my Muslim representation treatment does not affect peoples' self-reported likelihood of wearing a mask, leaving their home, or visiting friends and family.

\section{Conclusion}

In this paper I provide a first answer for a consequential yet under-explored question, namely: how does minority representation in public institutions shape intergroup relations? To do so, I build on several frameworks in social and political psychology (Wittenbrink, Judd and Park 2001; Blair 2002; Ramasubramanian 2007; Williamson 2019), and develop a theory of prejudice reduction 
through descriptive representation. Specifically, I argue that positive information about the role of minorities in public institutions reduces prejudice and promote preferences for political inclusion.

To test my theory, I focus on healthcare institutions and the role of minority workers within them. Through a series of survey experiments implemented during the hight of the first outbreak of COVID-19, I demonstrate that information regarding the role of Arab (Muslims) healthcare workers in Israeli (American) hospitals promotes more tolerant attitudes towards Arabs (Muslims). More so in the Israeli case, these effects extend beyond social measures of prejudice such as intergroup affect and trust, as information about representation in healthcare provision promotes more inclusive political preferences.

Interestingly, despite the diversionary consequences of polarization documented in both the Israeli and American contexts (Iyengar et al. 2019; Bassan-Nygate and Weiss 2020), the effects of information regarding representation are not moderated by respondents' partisan identity. Indeed right- and left-wing (Democrat and Republican) respondents react similarly to information regarding minority representation. More so, I find no support for backlash effects amongst more conservative respondents, or negative externalities around adherence to public health guidelines. Taken together, such uniform effects from Israel and the U.S. provide strong support for my theory of prejudice reduction through descriptive representation, suggesting that the demographic makeup of public institutions can have psychological effects, which promote more favorable intergroup relations.

However, this study is not without limitations. Like many other studies of representation in public institutions (Keiser et al. 2002; Riccucci, Van Ryzin and Lavena 2014; Riccucci, Van Ryzin and Li 2016; Nanes 2018), my empirical focus is on one institutional environment: healthcare provision. This in turn limits my ability to confidently generalize my findings to other types of institutions such as schools, tax collection agencies, or police forces.

My institutional focus was motivated by the centrality of healthcare institutions in developed countries (OECD 2019), as well as by previous studies which demonstrate the positive effects of minority representation on minority health outcomes (Alsan, Garrick and Graziani 2019). In many 
regards healthcare institutions are a most likely institutional context for my theory of prejudice reduction through representation, since representation in such institutions provides positive information regarding minority group members' competence, and general role in society. However, my theoretical framework should apply to additional institutional environments such as schools or welfare agencies, in which representation provides majority group members with positive information about minority group members. Testing this expectation, and identifying whether and how institutional environments moderate the effects of minority representation on prejudice is a promising avenue for future research.

\section{References}

Abu-Ras, W, LD Laird and F Sensai. 2012. "A window into American Muslim physicians: Civic engagement and community participation, their diversity, contributions \& challenges.” Washington, DC: Institute for Social Policy and Understanding .

Allport, Gordon W. 1954. The nature of prejudice. Unabridged, 25th anniversary ed ed. Reading, Mass.: Addison-Wesley Pub. Co.

Alsan, Marcella, Owen Garrick and Grant C Graziani. 2018. Does diversity matter for health? Experimental evidence from Oakland. Technical report National Bureau of Economic Research.

Alsan, Marcella, Owen Garrick and Grant Graziani. 2019. "Does diversity matter for health? Experimental evidence from Oakland.” American Economic Review 109(12):4071-4111.

Bar, Revital and Asaf Zussman. 2017. “Identity and Bias: Insights from Driving Tests.”.

Bar-Tal, Daniel. 1998. "Societal beliefs in times of intractable conflict: The Israeli case." International Journal of Conflict Management 9(1):22-50.

Barden, Jamie, William W Maddux, Richard E Petty and Marilynn B Brewer. 2004. "Contextual moderation of racial bias: the impact of social roles on controlled and automatically activated attitudes." Journal of personality and social psychology 87(1):5. 
Bassan-Nygate, Lotem and Chagai M. Weiss. 2020. "It's Us or Them: Partisan Polarization in Israel and Beyond." APSA MENA Politics Newsletter.

Beaman, Lori, Raghabendra Chattopadhyay, Esther Duflo, Rohini Pande and Petia Topalova. 2009. "Powerful women: does exposure reduce bias?" The Quarterly journal of economics 124(4):1497-1540.

Blair, Graeme, Alexander Coppock and Margaret Moor. Forthcoming. "When to worry about sensitivity bias: evidence from 30 years of list experiments." American Political Science Review

Blair, Irene V. 2002. “The malleability of automatic stereotypes and prejudice.” Personality and social psychology review 6(3):242-261.

Booth, William; and Karla Adam. 2020. "Boris Johnson praises immigrant nurses who saved his life, as Britain's NHS becomes a rallying cry.”.

URL: $\quad$ https://www.washingtonpost.com/world/europe/boris-johnson-nursesnhs/2020/04/13/51498d34-7bfa-11ea-a311-adb1344719a9_story.html

Broockman, David and Joshua Kalla. 2016. "Durably reducing transphobia: A field experiment on door-to-door canvassing." Science 352(6282):220-224.

Burns, Mason D, Margo J Monteith and Laura R Parker. 2017. “Training away bias: The differential effects of counterstereotype training and self-regulation on stereotype activation and application." Journal of Experimental Social Psychology 73:97-110.

Canetti-Nisim, Daphna, Gal Ariely and Eran Halperin. 2008. "Life, pocketbook, or culture: The role of perceived security threats in promoting exclusionist political attitudes toward minorities in Israel.” Political Research Quarterly 61(1):90-103.

Chauchard, Simon. 2014. "Can descriptive representation change beliefs about a stigmatized group? Evidence from rural India.” American political Science review 108(2):403-422. 
Coppock, Alexander and Oliver A McClellan. 2019. "Validating the demographic, political, psychological, and experimental results obtained from a new source of online survey respondents." Research \& Politics 6(1):2053168018822174.

Enos, Ryan D and Noam Gidron. 2016. "Intergroup behavioral strategies as contextually determined: Experimental evidence from Israel.” The Journal of Politics 78(3):851-867.

Enos, Ryan D and Noam Gidron. 2018. "Exclusion and Cooperation in Diverse Societies: Experimental Evidence from Israel.” American Political Science Review 112(4):742-757.

Fernandez, Sergio, Samuel Koma and Hongseok Lee. 2018. "Establishing the link between representative bureaucracy and performance: The South African case." Governance 31(3):535-553.

Gade, Daniel M and Vicky M Wilkins. 2012. "Where did you serve? Veteran identity, representative bureaucracy, and vocational rehabilitation." Journal of Public Administration Research and Theory 23(2):267-288.

Grossman, Guy, Devorah Manekin and Dan Miodownik. 2015. "The Political Legacies of Combat: Attitudes Toward War and Peace Among Israeli Ex-Combatants.” International Organization 69(04):981-1009.

Grossman, Guy, Devorah Manekin and Yotam Margalit. 2018. "How sanctions affect public opinion in target countries: Experimental evidence from Israel." Comparative Political Studies 51(14):1823-1857.

Grossman, Guy, Oren Gazal-Ayal, Samuel D Pimentel and Jeremy M Weinstein. 2016. “Descriptive representation and judicial outcomes in multiethnic societies." American Journal of Political Science 60(1):44-69.

Hajnal, Zoltan L. 2001. "White residents, black incumbents, and a declining racial divide." American Political Science Review 95(3):603-617. 
Hendrix, Steve. 2020. "An Arab doctor and an ultra-Orthodox Jew find common ground in a covid ward.” Washington Post .

Iyengar, Shanto, Yphtach Lelkes, Matthew Levendusky, Neil Malhotra and Sean J Westwood. 2019. "The origins and consequences of affective polarization in the United States." Annual Review of Political Science 22:129-146.

Jaffe-Hoffman, Maayan. 2020. "Israel Katz: The Joint List is full of terrorists in suits.”.

Kalkan, Kerem Ozan, Geoffrey C Layman and Eric M Uslaner. 2009. ““"Bands of others”? Attitudes toward Muslims in contemporary American society." The Journal of Politics 71(3):847862.

Kalla, Joshua L and David E Broockman. 2020. "Reducing exclusionary attitudes through interpersonal conversation: evidence from three field experiments." American Political Science Review 114(2):410-425.

Karim, Sabrina. 2019. "Restoring confidence in post-conflict security sectors: Survey evidence from Liberia on female ratio balancing reforms.” British Journal of Political Science pp. 1-23.

Karim, Sabrina. 2020. "Relational State Building in Areas of Limited Statehood: Experimental Evidence on Attitudes about the Police." American political science review .

Keiser, Lael R, Vicky M Wilkins, Kenneth J Meier and Catherine A Holland. 2002. "Lipstick and logarithms: Gender, institutional context, and representative bureaucracy." American political science review 96(3):553-564.

Kingsley, John Donald. 1944. "Representative bureaucracy.”.

Lajevardi, Nazita. Forthcoming. "The media matters: Muslim american portrayals and the effects on mass attitudes." The Journal of Politics . 
Lajevardi, Nazita and Marisa Abrajano. 2019. "How negative sentiment toward Muslim Americans predicts support for Trump in the 2016 Presidential Election.” The Journal of Politics 81(1):296302.

Lipsky, Michael. 1980. Street-level bureaucracy: Dilemmas of the individual in public service. Russell Sage Foundation.

Mansbridge, Jane. 1999. "Should blacks represent blacks and women represent women? A contingent" yes"." The Journal of politics 61(3):628-657.

McDermott, Rose. 2011. "Internal and external validity." Cambridge handbook of experimental political science pp. 27-40.

Meier, Kenneth John. 1975. "Representative bureaucracy: An empirical analysis." American political science review 69(2):526-542.

Mosher, Frederick C. 1968. Democracy and the public service. Oxford University Press on Demand.

Mummolo, Jonathan and Erik Peterson. 2019. "Demand effects in survey experiments: An empirical assessment." American Political Science Review 113(2):517-529.

Nanes, Matthew J. 2018. "Policing in divided societies: Officer inclusion, citizen cooperation, and crime prevention.” Conflict Management and Peace Science p. 0738894218802580.

Neggers, Yusuf. 2018. “Enfranchising Your Own? Experimental Evidence on Bureaucrat Diversity and Election Bias in India.” American Economic Review 108(6):1288-1321.

OECD. 2019. "Health at a Glance 2019: OECD Indicators." OECD Publishing, Paris .

Padela, Aasim I, Huda Adam, Maha Ahmad, Zahra Hosseinian and Farr Curlin. 2016. "Religious identity and workplace discrimination: A national survey of American Muslim physicians." AJOB Empirical Bioethics 7(3):149-159. 
Patel, Yash M, Dan P Ly, Tanner Hicks and Anupam B Jena. 2018. "Proportion of Non-US-Born and Noncitizen Health Care Professionals in the United States in 2016." Jama 320(21):22652267.

Pedahzur, Ami and Yael Yishai. 1999. "Hatred by hated people: Xenophobia in Israel." Studies in Conflict and Terrorism 22(2):101-117.

Pepinsky, Thomas B, Jan H Pierskalla and Audrey Sacks. 2017. "Bureaucracy and service delivery." Annual Review of Political Science 20:249-268.

Pitkin, Hanna F. 1967. The concept of representation. Vol. 75 Univ of California Press.

Ramasubramanian, Srividya. 2007. "Media-based strategies to reduce racial stereotypes activated by news stories.” Journalism \& Mass Communication Quarterly 84(2):249-264.

Ramasubramanian, Srividya and Mary Beth Oliver. 2007. “Activating and suppressing hostile and benevolent racism: Evidence for comparative media stereotyping." Media psychology 9(3):623646.

Rasul, Imran and Daniel Rogger. 2015. “The impact of ethnic diversity in bureaucracies: evidence from the Nigerian civil service.” American Economic Review 105(5):457-61.

Riccucci, Norma M, Gregg G Van Ryzin and Cecilia F Lavena. 2014. "Representative bureaucracy in policing: Does it increase perceived legitimacy?" Journal of public administration research and theory 24(3):537-551.

Riccucci, Norma M, Gregg G Van Ryzin and Huafang Li. 2016. "Representative bureaucracy and the willingness to coproduce: An experimental study." Public Administration Review 76(1):121130.

Rosenbloom, David H and Jeannette G Featherstonhaugh. 1977. "Passive and active representation in the federal service: A comparison of blacks and whites." Social Science Quarterly 57(4):873882. 
Rosner, Tal. 2016. “Heroes of Health: Israel's Healthcare System as a Model of Jewish-Arab Coexistence.” 13 King David St., Jeruslaem, Israel: .

Samooha, Sami. 2013. Lo Shovrim et Ha-Kelim: Madad Yahasei Aravim-Yehudim Be-Yisrael 2012. The University of Haifa and The Israeli Institute for Democracy.

Shayo, Moses and Asaf Zussman. 2011. "Judicial ingroup bias in the shadow of terrorism." The Quarterly Journal of Economics 126(3):1447-1484.

Sides, John and Kimberly Gross. 2013. "Stereotypes of Muslims and Support for the War on Terror." The Journal of Politics 75(3):583-598.

Smooha, Sammy. 2004. "Index of Arab-Jewish Relations in Israel." Haifa, Israel: The JewishArab Center, University of Haifa .

Tankard, Margaret E and Elizabeth Levy Paluck. 2017. "The effect of a Supreme Court decision regarding gay marriage on social norms and personal attitudes.” Psychological science 28(9):1334-1344.

Theobald, Nick A and Donald P Haider-Markel. 2008. "Race, bureaucracy, and symbolic representation: Interactions between citizens and police." Journal of Public Administration Research and Theory 19(2):409-426.

Tsfati, Yariv and Lilach Nir. 2017. "Frames and reasoning: Two pathways from selective exposure to affective polarization." International Journal of Communication 11:22.

Williamson, Scott. 2019. “Countering Misperceptions to Reduce Prejudice: An Experiment on Attitudes toward Muslim Americans." Journal of Experimental Political Science pp. 1-12.

Wittenbrink, Bernd, Charles M Judd and Bernadette Park. 2001. "Spontaneous prejudice in context: Variability in automatically activated attitudes." Journal of personality and social psychology 81(5):815. 
Wolsko, Christopher, Bernadette Park, Charles M Judd and Jonathan Bachelor. 2003. "Intergroup contact: Effects on group evaluations and perceived variability." Group Processes \& Intergroup Relations 6(1):93-110.

Yaron, Lee. 2020. “Arab Doctors are Leading the Battle against the Coronavirus and they Feel they have a Target on their Backs.”.

URL: https://www.haaretz.co.il/news/health/.premium-MAGAZINE-1.8682178

Zeitoun, Yoav; and Zvika Brot. 2020. "Yair Lapid Clarifies: I will not join a Political Block.". URL: https://www.ynet.co.il/articles/0,7340,L-4336345,00.html

Zussman, Asaf. 2013. "Ethnic discrimination: Lessons from the Israeli online market for used cars.” The Economic Journal 123(572):F433-F468. 


\section{Representation in Healthcare Institutions Promotes Intergroup \\ Tolerance}

Supplementary Information

A Israeli Study

A.1 Survey Instrument . . . . . . . . . . . . . . . . . . . . . SI-1

A.2 Additional Analyses . . . . . . . . . . . . . . . . . . SI-3

B U.S. Study

SI-12

B.1 Survey Instrument . . . . . . . . . . . . . . . . . . . . . SI-13

B.2 Additional Analyses . . . . . . . . . . . . . . . . . . SI-16 


\section{A Israeli Study}

My Israeli experiment was embedded within a brief public opinion survey distributed amongst a representative sample of 1,366 Jewish Israelis. I report descriptive statistics of all variables employed in my analysis in Table A1. In addition, I provide an elaborate description of my survey in section A.1 below.

\section{A.1 Survey Instrument}

My survey included four main sections: i) pre-treatment demographic questions, ii) an experimental vignette (see Figure 3 in the main text), iii) outcome measures, and iv) a series of manipulation checks. In this section I outline all variables collected as part of my survey.

\section{- Informed Consent}

\section{- Demographic Questions}

- Gender (Male / Female)

- Age Group (28-22 / 23-39 / 30-39 / 40-49 / 50-70)

- Ethnicity (Ashkenazi / Mizrachi / Mixed / Russian or USSR / Ethiopian / Other)

- Religiosity (Secular / Traditional / Religious / Ultra-Orthodox)

- Locality (02 - Jerusalem Area / 03 - Tel-Aviv and Central District / 04 - Haifa and Norther District / 08 - Souther District / 09 - Sharon District)

- Education (Elementary or less / High School / Professional Training / Partial Academic Degree / BA / MA+)

- Political Ideology (1:7 Right Left Scale)

- Exact Age

\section{- Experimental Vignette}

\section{- Outcome Measures}


- Feeling Thermometers (0-100 Scale)

* Left-Wing Supporters

* Right-Wing Supporters

* Arabs

- Social Exclusion (1:7 Scale - Would not accept in country / Would accept as visitor in country / Would accept as citizen in country / Would accept as co-worker / Would accept as neighbor / Would accept as close friend / Would accept as family member)

* Left-Wing Supporters

* Right-Wing Supporters

* Arabs

- Additional Measures of Intergroup Relations - Do you agree that:

* Most Arabs can be trusted (1:7 Agree Disagree)

* Most Arabs want to live in peace (1:7 Agree Disagree)

* Arabs should serve as leaders of Knesset committees (1:7 Agree Disagree)

- Social Norms - Do you agree that:

* Most Israelis would be willing to receive treatment from Arab doctors (1:7 Agree Disagree)

* Most Israelis would be willing to be friends with Arabs (1:7 Agree Disagree)

* Most Israelis would be willing to work for an Arab Boss (1:7 Agree Disagree)

* Most Israelis would support the idea that Arab MKs serve as leaders of Knesset committees (1:7 Agree Disagree)

\section{- Manipulation Checks}

- Do you agree that:

* The effects of the virus on Israeli society will be severe 
* Arab doctors are in the forefront of combatting the coronavirus

* There are many MKs that oppose including members of the Arab Joint list in key positions within the government

Table A1: Descriptive Statistics - Survey Respondents (Israel)

\begin{tabular}{lccccccc}
\hline Statistic & $\mathrm{N}$ & Mean & St. Dev. & Min & Pctl(25) & Pctl(75) & Max \\
\hline \hline Male & 1,365 & 0.465 & 0.499 & 0.000 & 0.000 & 1.000 & 1.000 \\
Age & 1,366 & 41.539 & 14.780 & 18 & 28 & 53 & 73 \\
Secular & 1,366 & 0.496 & 0.500 & 0 & 0 & 1 & 1 \\
Traditional & 1,366 & 0.337 & 0.473 & 0 & 0 & 1 & 1 \\
Religious & 1,366 & 0.138 & 0.345 & 0 & 0 & 0 & 1 \\
Ultra-Orthodox & 1,366 & 0.028 & 0.165 & 0 & 0 & 0 & 1 \\
Jerusalem Area & 1,366 & 0.117 & 0.322 & 0 & 0 & 0 & 1 \\
Tel-Aviv & 1,366 & 0.309 & 0.462 & 0 & 0 & 1 & 1 \\
Haifa and North & 1,366 & 0.247 & 0.431 & 0 & 0 & 0 & 1 \\
South & 1,366 & 0.230 & 0.421 & 0 & 0 & 0 & 1 \\
Sharon & 1,366 & 0.097 & 0.297 & 0 & 0 & 0 & 1 \\
Less than HS & 1,366 & 0.007 & 0.081 & 0 & 0 & 0 & 1 \\
HS & 1,366 & 0.242 & 0.428 & 0 & 0 & 0 & 1 \\
Partial Academic & 1,366 & 0.073 & 0.261 & 0 & 0 & 0 & 1 \\
Non-Academic Degree & 1,366 & 0.223 & 0.416 & 0 & 0 & 0 & 1 \\
BA & 1,366 & 0.294 & 0.456 & 0 & 0 & 1 & 1 \\
MA+ & 1,366 & 0.162 & 0.368 & 0 & 0 & 0 & 1 \\
LR Scale & 1,366 & 2.998 & 1.626 & 1 & 2 & 4 & 7 \\
Therm Arabs & 1,363 & 42.403 & 24.572 & 0.000 & 24.000 & 52.000 & 100.000 \\
Exclusion Arabs & 1,356 & 4.125 & 1.917 & 1.000 & 3.000 & 6.000 & 7.000 \\
Trust Arabs & 1,354 & 4.312 & 1.701 & 1.000 & 3.000 & 6.000 & 7.000 \\
Peace Arabs & 1,354 & 4.723 & 1.605 & 1.000 & 4.000 & 6.000 & 7.000 \\
Pol Inc Arabs & 1,354 & 3.553 & 1.961 & 1.000 & 2.000 & 5.000 & 7.000 \\
Manip - Doctor & 1,351 & 5.111 & 1.538 & 1.000 & 4.000 & 6.000 & 7.000 \\
Manip - Severity & 1,351 & 5.641 & 1.402 & 1.000 & 5.000 & 7.000 & 7.000 \\
Manip - Exclusion & 1,351 & 5.655 & 1.326 & 1.000 & 5.000 & 7.000 & 7.000 \\
\hline \hline
\end{tabular}

\section{A.2 Additional Analyses}

\section{A.2.1 Manipulation Checks}

In Table A2 I assess the effectiveness of my treatment by leveraging three manipulation check questions. Specifically, to consider the extent to which my treatments impacted respondents' per- 
spectives regarding i) Arab representation in healthcare institutions, ii) Crisis severity, and iii) Israeli politicians exclusionary statements, I regressed responses to the last three question in my survey (see section above), over treatment indicators.

Results from Table A2 suggest that my Arab representation treatment increased respondents' perception that Arab healthcare workers are at the forefront of combatting the coronavirus (column 1). In addition, it appears that respondents who were provided additional information regarding the severity of the COVID-19 crises were more likely to evaluate the COVID-19 crisis as a severe threat for Israeli society (column 2). That said, the null effects in column 3, suggest that my political exclusion treatment was ineffective in shaping respondents perspectives regarding the prevalence of preferences for exclusion amongst politicians. This may be driven by the salience of such preferences, which are common knowledge to many survey respondents.

Table A2: Manipulation Check

\begin{tabular}{lccc}
\hline \hline & Doctor Role & Severity of Crisis & Arab Exclusion \\
& $(1)$ & $(2)$ & $(3)$ \\
\hline Arab Treatment & 0.176 & & \\
& $(0.079)$ & & \\
Severity Treatment & & 0.151 & \\
Exclusion Treatment & & $(0.072)$ & 0.043 \\
$N$ & & & $(0.068)$ \\
\hline \hline
\end{tabular}

\section{A.2.2 Balance and Robustness Checks}

In table A3 I present results from balance tests comparing respondents across the two conditions of my main treatment relating to Arab representation in Israeli healthcare institutions. As noted in the main text, despite randomization there is a small albeit statistically significant difference in gender across conditions. To ensure that my identified effects are not confounded by gender, in Figure A1 I present a set of additional analyses, with alternative specification to my main pre-registered model.

Figure A1 demonstrates that my main results remain robust when controlling for gender (see 
Table A3: Balance on Covariates (Israeli Sample)

\begin{tabular}{llrrrrr}
\hline & Variable & Treatment N & Control N & Treatment Mean & Control Mean & p. Value \\
\hline 1 & Age & 680 & 686 & 41.81 & 41.27 & 0.50 \\
2 & Male & 680 & 685 & 0.44 & 0.49 & 0.05 \\
3 & Education & 680 & 686 & 2.70 & 2.69 & 0.90 \\
4 & Ethnicity & 680 & 686 & 1.43 & 1.49 & 0.50 \\
5 & Ideology & 680 & 686 & 3.01 & 2.98 & 0.75 \\
6 & Religiosity & 680 & 686 & 0.74 & 0.66 & 0.08 \\
\hline
\end{tabular}

blue-triangle coefficients), additional treatment arms (see green-square coefficients), and an exhaustive set of individual-level covariates (see purple-cross coefficients). These additional models strengthen my confidence in the identified effects presented in the main text.

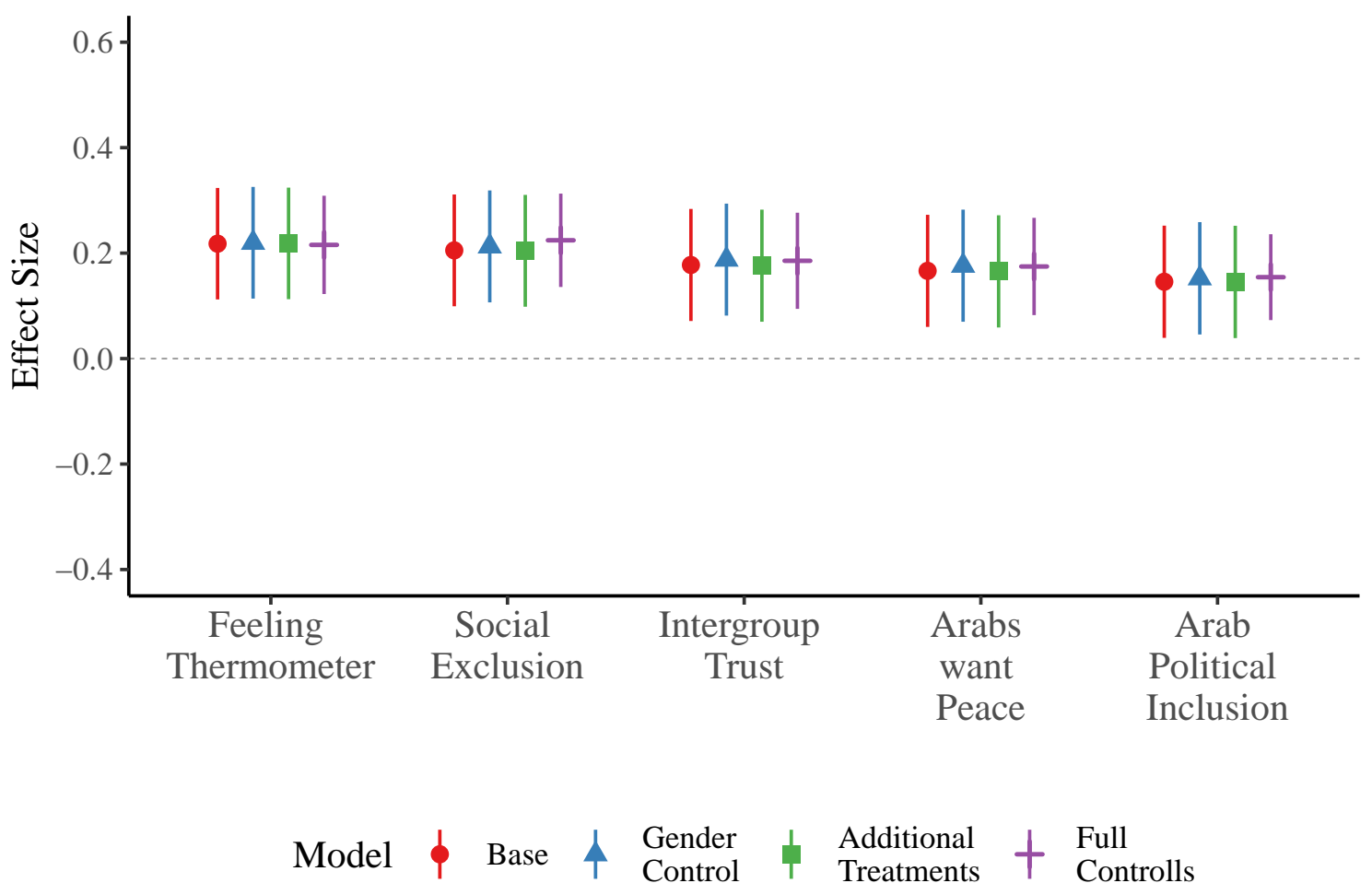

Figure A1: Israeli Experiment Robustness to Alternative Specifications - OLS point estimates and their corresponding confidence intervals represent the average treatment effect of information regarding Arab representation on prejudice attitudes and preferences for political exclusion. The full control model include the following covariates: age, gender, ethnicity, religiosity, locality, and education.

In Figure A2 I present results from a placebo test. In this test, I consider whether my Arab representation treatment shifted attitudes towards other social groups. In large, my main treatment 
did not affect general affect, or attitudes of social exclusion towards Right-Wing partisans. In addition, I do not detect a treatment effect on respondents' preferences of social exclusion towards left-wing supporters. That said, I do find a small effect, which approaches conventional levels of statistical significance when considering general affect towards Left-Wing partisans. This may be driven by the fact that respondents link between Arabs, Arab doctors, and left-wing partisans. However, more generally, I construe these findings as supportive of the idea, that my treatment facilitates updating with regards to the represented minority group (i.e. Arabs).

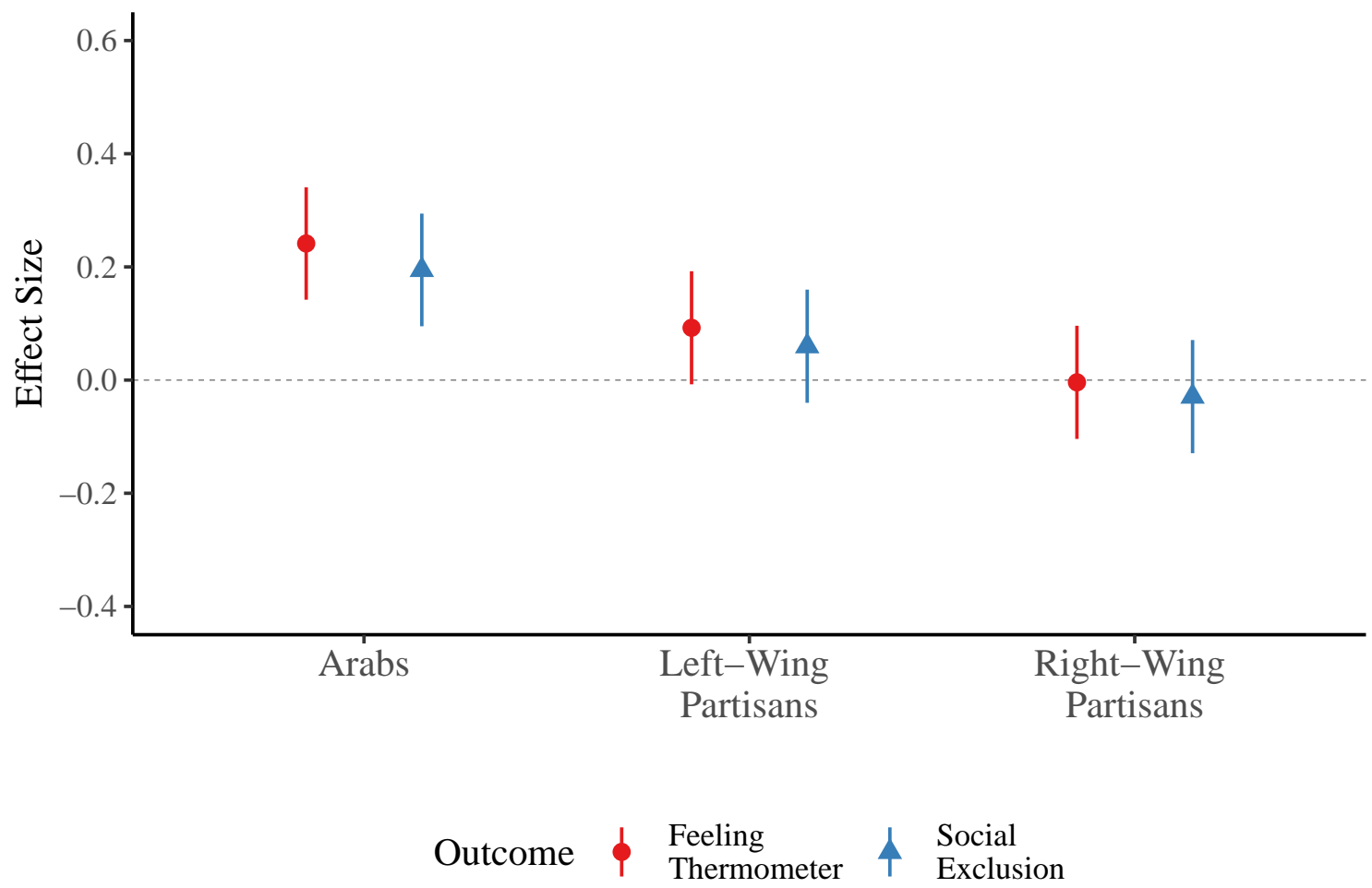

Figure A2: Placebo Test - OLS point estimates and their corresponding confidence intervals represent the average treatment effect of information regarding Arab representation on prejudice attitudes towards Arabs, Left-Wing Partisans, and Right-Wing Partisans.

\section{A.2.3 Heterogenous Treatment Effects}

In this section, I report a series of pre-registered heterogenous treatment effects. In my original pre-analysis plan, I expected that emphasizing the severity of the COVID-19 crisis would amplify the average treatment effects of representation, whereas emphasizing politicians' preferences for political exclusion of Arabs would dampen average treatment effects. In Tables A4-A5 I consider 
these possibilities by interacting my representation treatment with a binary variable taking the value of one for respondents primed with the severity or exclusion treatments. As demonstrated in these tables, I do not find support for these expectations, as the effects of representation are not moderated by the severity of the COVID-19 crisis. However, my ability to speak about the moderating effects of politicians' exclusionary statements is rather limited, since the manipulation checks presented in Table A2 suggest that unlike my representation and severity treatments, the exclusion treatment was unsuccessful in shaping respondents' perceptions regarding the prevalence of political exclusion.

Table A4: Heterogenous Treatment Effect of Arab Representation Conditional on Severity Treatment

\begin{tabular}{lccccc}
\hline \hline & Therm & Exclusion & Trust & Peace & Pol Inc \\
& $(1)$ & $(2)$ & $(3)$ & $(4)$ & $(5)$ \\
\hline Representation & 0.263 & 0.245 & 0.204 & 0.199 & 0.257 \\
& $(0.076)$ & $(0.076)$ & $(0.076)$ & $(0.076)$ & $(0.076)$ \\
Severity & 0.056 & -0.025 & -0.015 & 0.032 & 0.119 \\
& $(0.076)$ & $(0.076)$ & $(0.076)$ & $(0.076)$ & $(0.076)$ \\
Representation*Severity & -0.091 & -0.080 & -0.053 & -0.067 & -0.226 \\
& $(0.108)$ & $(0.108)$ & $(0.108)$ & $(0.108)$ & $(0.108)$ \\
$N$ & 1,363 & 1,356 & 1,354 & 1,354 & 1,354 \\
\hline \hline
\end{tabular}

Table A5: Heterogenous Treatment Effect of Arab Representation Conditional on Exclusion Treatment

\begin{tabular}{lccccc}
\hline \hline & Therm & Exclusion & Trust & Peace & Pol Inc \\
& $(1)$ & $(2)$ & $(3)$ & $(4)$ & $(5)$ \\
\hline Representation & 0.211 & 0.153 & 0.119 & 0.147 & 0.120 \\
Exclusion & $(0.075)$ & $(0.076)$ & $(0.076)$ & $(0.076)$ & $(0.076)$ \\
& -0.035 & -0.010 & 0.002 & 0.025 & -0.013 \\
Representation*Exclusion & $(0.076)$ & $(0.076)$ & $(0.076)$ & $(0.077)$ & $(0.077)$ \\
& 0.016 & 0.106 & 0.117 & 0.038 & 0.052 \\
$N$ & $(0.108)$ & $(0.108)$ & $(0.108)$ & $(0.108)$ & $(0.109)$ \\
\hline \hline
\end{tabular}

In Table A6 I consider the possibility that older high-risk respondents' report stronger treatment 
effects. The motivation for this expectation is similar to the motivation around the moderating effects of crisis severity. Specifically, one may expect that respondents which are more threatened by the pandemic, may appreciate the role of Arab healthcare workers to a greater extent, and thus report higher degrees of prejudice reduction. To consider this possibility, I created a binary indicator taking a value of one for respondents ages 65 and up, ${ }^{16}$ which I interacted with my main treatment regarding Arab representation. Results from Table A6 suggest that older respondents who are more vulnerable to COVID-19, do not report different reaction to my treatment.

Table A6: Heterogenous Treatment Effect of Arab Representation Conditional on Vulnerable Age

\begin{tabular}{lccccc}
\hline \hline & Therm & SD & Trust & Peace & Pol Inc \\
& $(1)$ & $(2)$ & $(3)$ & $(4)$ & $(5)$ \\
\hline Representation & 0.235 & 0.255 & 0.208 & 0.190 & 0.193 \\
& $(0.053)$ & $(0.052)$ & $(0.053)$ & $(0.053)$ & $(0.051)$ \\
$65+$ & 0.181 & 0.316 & 0.214 & 0.178 & 0.292 \\
& $(0.146)$ & $(0.141)$ & $(0.146)$ & $(0.146)$ & $(0.138)$ \\
Representation*65+ & 0.021 & -0.076 & 0.002 & 0.113 & -0.198 \\
& $(0.207)$ & $(0.201)$ & $(0.207)$ & $(0.207)$ & $(0.196)$ \\
Controls & Yes & Yes & Yes & Yes & Yes \\
$N$ & 1,362 & 1,355 & 1,353 & 1,353 & 1,353 \\
\hline \hline
\end{tabular}

Notes:

Controls include: age, gender, ethnicity, religiosity, education, and indicators for exclusion and severity treatments.

In Tables A7-A10 I provide a series of additional robustness checks relating to the (lack of) moderating effects of partisanship on my main treatment - Arab representation. Specifically, expanding on Table 2 of the main text, where interact a seven point ideology scale with my main treatment, I further consider a fully saturated model where I divide the seven-point scale into binary indicators, which are interacted with my main treatment. Doing so, I do not find any support that ideology moderates treatment effects.

In addition, I consider the extent to which "strong" partisans or centrists react differently to my treatment. To do so, I created three binary indicators: Left - taking a value of 1 for respondents

\footnotetext{
${ }^{16}$ Citizens above the age of 65 were identified by the Israeli Ministry of Health as "at risk".
} 
Table A7: Heterogenous Treatment Effect of Arab Representation Conditional on Ideology (Fully Saturated Model)

\begin{tabular}{|c|c|c|c|c|c|}
\hline & $\begin{array}{c}\text { Therm } \\
\text { (1) }\end{array}$ & $\begin{array}{l}\mathrm{SD} \\
(2)\end{array}$ & $\begin{array}{l}\text { Trust } \\
\text { (3) }\end{array}$ & $\begin{array}{c}\text { Peace } \\
(4)\end{array}$ & $\begin{array}{c}\text { Pol Inc } \\
\text { (5) }\end{array}$ \\
\hline Representation & $\begin{array}{c}0.213 \\
(0.095)\end{array}$ & $\begin{array}{c}0.313 \\
(0.089)\end{array}$ & $\begin{array}{c}0.252 \\
(0.092)\end{array}$ & $\begin{array}{c}0.176 \\
(0.093)\end{array}$ & $\begin{array}{c}0.185 \\
(0.082)\end{array}$ \\
\hline Center-Left & $\begin{array}{c}-0.144 \\
(0.110)\end{array}$ & $\begin{array}{l}-0.056 \\
(0.103)\end{array}$ & $\begin{array}{c}-0.065 \\
(0.107)\end{array}$ & $\begin{array}{l}-0.151 \\
(0.108)\end{array}$ & $\begin{array}{l}-0.319 \\
(0.095)\end{array}$ \\
\hline Center-Right & $\begin{array}{c}0.449 \\
(0.130)\end{array}$ & $\begin{array}{c}0.598 \\
(0.123)\end{array}$ & $\begin{array}{c}0.632 \\
(0.127)\end{array}$ & $\begin{array}{c}0.361 \\
(0.129)\end{array}$ & $\begin{array}{c}0.659 \\
(0.113)\end{array}$ \\
\hline Left & $\begin{array}{c}-0.351 \\
(0.108)\end{array}$ & $\begin{array}{c}-0.531 \\
(0.102)\end{array}$ & $\begin{array}{c}-0.483 \\
(0.106)\end{array}$ & $\begin{array}{c}-0.544 \\
(0.107)\end{array}$ & $\begin{array}{l}-0.632 \\
(0.094)\end{array}$ \\
\hline Right & $\begin{array}{c}-0.606 \\
(0.097)\end{array}$ & $\begin{array}{c}-0.787 \\
(0.091)\end{array}$ & $\begin{array}{c}-0.755 \\
(0.095)\end{array}$ & $\begin{array}{l}-0.936 \\
(0.096)\end{array}$ & $\begin{array}{l}-0.835 \\
(0.084)\end{array}$ \\
\hline Strong Left & $\begin{array}{c}0.847 \\
(0.191)\end{array}$ & $\begin{array}{c}0.369 \\
(0.180)\end{array}$ & $\begin{array}{c}0.731 \\
(0.186)\end{array}$ & $\begin{array}{c}0.435 \\
(0.189)\end{array}$ & $\begin{array}{c}0.866 \\
(0.165)\end{array}$ \\
\hline Strong Right & $\begin{array}{c}0.084 \\
(0.153)\end{array}$ & $\begin{array}{l}-0.106 \\
(0.144)\end{array}$ & $\begin{array}{l}-0.070 \\
(0.149)\end{array}$ & $\begin{array}{c}-0.056 \\
(0.151)\end{array}$ & $\begin{array}{c}0.113 \\
(0.132)\end{array}$ \\
\hline Representation*Center-Left & $\begin{array}{l}-0.062 \\
(0.190)\end{array}$ & $\begin{array}{c}-0.330 \\
(0.180)\end{array}$ & $\begin{array}{l}-0.257 \\
(0.186)\end{array}$ & $\begin{array}{c}-0.110 \\
(0.188)\end{array}$ & $\begin{array}{l}-0.079 \\
(0.165)\end{array}$ \\
\hline Representation*Center-Right & $\begin{array}{c}0.046 \\
(0.147)\end{array}$ & $\begin{array}{l}-0.022 \\
(0.138)\end{array}$ & $\begin{array}{c}-0.138 \\
(0.143)\end{array}$ & $\begin{array}{l}-0.085 \\
(0.145)\end{array}$ & $\begin{array}{l}-0.179 \\
(0.127)\end{array}$ \\
\hline Representation*Left & $\begin{array}{l}-0.235 \\
(0.250)\end{array}$ & $\begin{array}{l}-0.099 \\
(0.235)\end{array}$ & $\begin{array}{l}-0.160 \\
(0.244)\end{array}$ & $\begin{array}{l}-0.120 \\
(0.247)\end{array}$ & $\begin{array}{c}0.118 \\
(0.217)\end{array}$ \\
\hline Representation*Right & $\begin{array}{l}-0.068 \\
(0.135)\end{array}$ & $\begin{array}{c}-0.216 \\
(0.127)\end{array}$ & $\begin{array}{c}-0.052 \\
(0.131)\end{array}$ & $\begin{array}{c}0.095 \\
(0.133)\end{array}$ & $\begin{array}{l}-0.071 \\
(0.117)\end{array}$ \\
\hline Representation*Strong Left & $\begin{array}{c}0.151 \\
(0.295)\end{array}$ & $\begin{array}{c}0.144 \\
(0.277)\end{array}$ & $\begin{array}{c}0.145 \\
(0.291)\end{array}$ & $\begin{array}{c}0.196 \\
(0.295)\end{array}$ & $\begin{array}{c}0.106 \\
(0.259)\end{array}$ \\
\hline Controls & Yes & Yes & Yes & Yes & Yes \\
\hline$N$ & 1,362 & 1,355 & 1,353 & 1,353 & 1,353 \\
\hline
\end{tabular}

Notes:

Controls include: age, gender, ethnicity, religiosity, education, and indicators for exclusion and severity treatments. 
scoring 6-7 on the ideology scale, Right - taking a value of 1 for respondents scoring 1-2 on the ideology scale, and Center - taking a value of 1 for respondents scoring 4 on the ideology scale. When interacting these indicators with my main treatment in Tables A8-A10, I find no evidence that strong partisans or centrists respond to my treatment in a unique fashion. Indeed, these additional analyses bolster my confidence that information regarding Arab representation in Israeli healthcare institutions has a uniform effect on Israeli Jewish citizens.

Table A8: Heterogenous Treatment Effect of Arab Representation Conditional on Strong Left Ideology

\begin{tabular}{lccccc}
\hline \hline & Therm & SD & Trust & Peace & Pol Inc \\
& $(1)$ & $(2)$ & $(3)$ & $(4)$ & $(5)$ \\
\hline Representation & 0.227 & 0.223 & 0.190 & 0.181 & 0.152 \\
& $(0.052)$ & $(0.051)$ & $(0.052)$ & $(0.053)$ & $(0.048)$ \\
Left & 1.004 & 0.629 & 0.878 & 0.707 & 0.976 \\
& $(0.141)$ & $(0.139)$ & $(0.141)$ & $(0.143)$ & $(0.132)$ \\
Representation*Left & -0.091 & 0.150 & 0.027 & 0.017 & 0.140 \\
& $(0.190)$ & $(0.187)$ & $(0.191)$ & $(0.193)$ & $(0.178)$ \\
Controls & Yes & Yes & Yes & Yes & Yes \\
$N$ & 1,362 & 1,355 & 1,353 & 1,353 & 1,353 \\
\hline \hline
\end{tabular}

Notes:

Controls include: age, gender, ethnicity, religiosity, education, and indicators for exclusion and severity treatments. 
Table A9: Heterogenous Treatment Effect of Arab Representation Conditional on Strong Right Ideology

\begin{tabular}{lccccc}
\hline \hline & Therm & SD & Trust & Peace & Pol Inc \\
& $(1)$ & $(2)$ & $(3)$ & $(4)$ & $(5)$ \\
\hline Representation & 0.221 & 0.240 & 0.191 & 0.143 & 0.213 \\
& $(0.065)$ & $(0.061)$ & $(0.063)$ & $(0.063)$ & $(0.058)$ \\
Right & -0.596 & -0.785 & -0.773 & -0.818 & -0.803 \\
& $(0.076)$ & $(0.071)$ & $(0.074)$ & $(0.074)$ & $(0.068)$ \\
Representation*Right & -0.010 & -0.039 & -0.014 & 0.070 & -0.139 \\
& $(0.100)$ & $(0.094)$ & $(0.097)$ & $(0.097)$ & $(0.089)$ \\
Controls & Yes & Yes & Yes & Yes & Yes \\
$N$ & 1,362 & 1,355 & 1,353 & 1,353 & 1,353 \\
\hline \hline
\end{tabular}

Notes:

Controls include: age, gender, ethnicity, religiosity, education, and indicators for exclusion and severity treatments.

Table A10: Heterogenous Treatment Effect of Arab Representation Conditional on Center Ideology

\begin{tabular}{lccccc}
\hline \hline & Therm & SD & Trust & Peace & Pol Inc \\
& $(1)$ & $(2)$ & $(3)$ & $(4)$ & $(5)$ \\
\hline Representation & 0.227 & 0.210 & 0.175 & 0.189 & 0.159 \\
& $(0.059)$ & $(0.058)$ & $(0.060)$ & $(0.059)$ & $(0.056)$ \\
Center & 0.068 & 0.162 & 0.106 & 0.272 & 0.192 \\
& $(0.084)$ & $(0.081)$ & $(0.084)$ & $(0.084)$ & $(0.079)$ \\
Representation*Center & 0.019 & 0.142 & 0.116 & 0.023 & 0.072 \\
& $(0.119)$ & $(0.115)$ & $(0.118)$ & $(0.118)$ & $(0.112)$ \\
Controls & Yes & Yes & Yes & Yes & Yes \\
$N$ & 1,362 & 1,355 & 1,353 & 1,353 & 1,353 \\
\hline \hline
\end{tabular}

Notes:

Controls include: age, gender, ethnicity, religiosity, education, and indicators for exclusion and severity treatments. 


\section{B U.S. Study}

My U.S experiment was embedded within a brief public opinion survey distributed amongst a representative sample of 1216 non-Musilim U.S. survey respondents. I report descriptive statistics of all variables employed in my analysis in Table A11. In addition, I provide an elaborate description of my survey in section B.1 below.

Table A11: Descriptive Statistics - Survey Respondents (US)

\begin{tabular}{lccccccc}
\hline Statistic & $\mathrm{N}$ & Mean & St. Dev. & Min & Pctl(25) & Pctl(75) & Max \\
\hline \hline Male & 1,211 & 0.453 & 0.498 & 0 & 0 & 1 & 1 \\
Age & 1,211 & 48.277 & 16.505 & 16 & 35 & 62 & 95 \\
White & 1,210 & 0.745 & 0.436 & 0.000 & 0.000 & 1.000 & 1.000 \\
Hispanic & 1,210 & 0.076 & 0.265 & 0.000 & 0.000 & 0.000 & 1.000 \\
African American & 1,210 & 0.108 & 0.311 & 0.000 & 0.000 & 0.000 & 1.000 \\
Asian & 1,210 & 0.044 & 0.205 & 0.000 & 0.000 & 0.000 & 1.000 \\
Protestant & 1,211 & 0.268 & 0.443 & 0 & 0 & 1 & 1 \\
Catholic & 1,211 & 0.293 & 0.455 & 0 & 0 & 1 & 1 \\
Atheist & 1,211 & 0.128 & 0.334 & 0 & 0 & 0 & 1 \\
Jewish & 1,211 & 0.027 & 0.163 & 0 & 0 & 0 & 1 \\
Buddhist & 1,211 & 0.014 & 0.118 & 0 & 0 & 0 & 1 \\
Hindu & 1,211 & 0.007 & 0.081 & 0 & 0 & 0 & 1 \\
Education & 1,211 & 4.540 & 1.908 & 1 & 2 & 6 & 8 \\
Democrat & 1,211 & 0.372 & 0.483 & 0 & 0 & 1 & 1 \\
Republican & 1,211 & 0.336 & 0.473 & 0 & 0 & 1 & 1 \\
Idenpendent & 1,211 & 0.261 & 0.439 & 0 & 0 & 1 & 1 \\
Other Party & 1,211 & 0.031 & 0.174 & 0 & 0 & 0 & 1 \\
COVID Medical Risk & 1,211 & 0.336 & 0.473 & 0 & 0 & 1 & 1 \\
Thermometer (Muslims) & 1,193 & 58.453 & 29.928 & 0.000 & 47.000 & 83.000 & 100.000 \\
Social Exclusion (Muslims) & 1,188 & 4.889 & 1.884 & 1.000 & 4.000 & 7.000 & 7.000 \\
Trust (Muslims) & 1,186 & 5.031 & 1.670 & 1.000 & 4.000 & 6.000 & 7.000 \\
Peace (Muslims) & 1,186 & 5.363 & 1.544 & 1.000 & 5.000 & 7.000 & 7.000 \\
Political Inclusion (Muslims) & 1,186 & 4.474 & 1.776 & 1.000 & 4.000 & 6.000 & 7.000 \\
Doctor Manipulation & 1,176 & 4.776 & 1.500 & 1.000 & 4.000 & 6.000 & 7.000 \\
Severity Manipulation & 1,176 & 5.864 & 1.317 & 1.000 & 5.000 & 7.000 & 7.000 \\
Exclusion Manipulation & 1,176 & 4.960 & 1.495 & 1.000 & 4.000 & 6.000 & 7.000 \\
\hline \hline
\end{tabular}




\section{B.1 Survey Instrument}

My survey included five main sections: i) pre-treatment demographic questions, ii) an experimental vignette (see Figure A3 below), iii) questions regarding social distancing practices, iv) outcome measures, and v) a series of manipulation checks. In this section I outline all variables collected as part of my survey.

\section{- Informed Consent}

\section{- Demographic Questions}

- Gender (Male / Female / Other)

- Race (White / Black or African American / Hispanic / Asian / Native Hawaiian, or other Pacific Islander / American Indian, or Alaskan Native / More than one Race / Other)

- Religion (Protestant / Catholic / Jewish / Muslim / Hindu / Buddhist / Atheist or Agnostic / Other)

- State (Drop-down menu of all U.S. states)

- Education (Some High-School / High School / Some College / Associate Degree or Vocational Training / College Graduate / Masters or Professional Degree / Ph.D)

- Political Ideology (1:7 Right Left Scale)

- Partisanship (Republican / Democrat / Independent / Some Other Party)

* If response above == "Republican" or "Democrat": Are you a strong or not very strong Republican/Democrat

- Age

- Medical Conditions which pose vulnerability with regards to COVID-19 (Obesity / Diabetes / Kidney Disease / Liver Disease / Medical Condition which Compromises the Immune System / Chronic Heat Illness / I Do Not Have Any of these Conditions)

\section{- Experimental Vignette}




\section{- Social Distancing Practices}

- How likely are you to adapt the following behaviors?

* Avoid visiting friends and family

* Limit time spent out of your house

* Wear a face mask

- Feeling thermometer (1:100 scale)

* Democrats

* Republicans

* Hispanics

* Muslims

* African Americans

* Asians

- Social Exclusion (1:7 Scale - Would not accept in country / Would accept as visitor in country / Would accept as citizen in country / Would accept as co-worker / Would accept as neighbor / Would accept as close friend / Would accept as family member)

* Democrats

* Republicans

* Hispanics

* Muslims

* African Americans

* Asians

- Additional Measures of Intergroup Relations - Do you agree that:

* Most Muslims in the U.S. can be trusted (1:7 Agree Disagree)

* Most Muslims in the U.S want to live in peace (1:7 Agree Disagree) 
* Muslim elected officials should be leading congressional committees (1:7 Agree Disagree)

- Immigration Questions - Do you agree that:

* Muslim Immigrants are generally good for American economy (1:7 Agree Disagree)

* America's culture is generally harmed by Muslim immigrants (1:7 Agree Disagree)

* Muslim immigrants take away jobs from American citizens (1:7 Agree Disagree)

- Norms Questions - Do you agree that:

* Most Americans would be willing to receive treatment from Muslim doctors (1:7 Agree Disagree)

* Most Americans would be willing to be friends with a Muslim (1:7 Agree Disagree)

* Most Americans would be willing to work for a Muslim Boss (1:7 Agree Disagree)

* Most Americans support having Muslim elected officials leading congressional committees (1:7 Agree Disagree)

- Integration Questions - Do you agree that:

* Most Muslims would like to be friends with non-Muslim Americans (1:7 Agree Disagree)

* Most Muslims would like to work for a non-Muslim boss (1:7 Agree Disagree)

* Most Muslims would be willing to receive treatment from a non-Muslim doctor (1:7 Agree Disagree)

* Most Muslims work hard to integrate into American society (1:7 Agree Disagree)

\section{- Manipulation Checks}

- Do you agree that: 
* The impact of COVID-19 on American society will be extremely severe (1:7 Agree Disagree)

* In the U.S., Muslim doctors are at the forefront of combatting the Coronavirus (1:7 Agree Disagree)

* Over the past few years, some politicians have promoted or supported policy aiming to ban immigration from Muslim countries (1:7 Agree Disagree)

\section{B.2 Additional Analyses}

\section{B.2.1 Manipulation Checks}

In Table A12 I assess the effectiveness of my treatment by leveraging three manipulation check questions. Specifically, to consider the extent to which my treatments impacted respondents' perspectives regarding: i) Muslim representation in healthcare institutions, ii) Crisis severity, and iii) politicians exclusionary preferences towards Muslims, I regressed responses to the last three question in my survey (see section above), over my main treatment indicators.

Table A12: Manipulation Check (US)

\begin{tabular}{lccc}
\hline \hline & Doctor Role & Severity of Crisis & Muslim Exclusion \\
& $(1)$ & $(2)$ & $(3)$ \\
\hline Muslim Treatment & 0.264 & & \\
Severity Treatment & $(0.087)$ & & \\
& & 0.021 & \\
Exclusion Treatment & & $(0.077)$ & 0.061 \\
& & & $(0.087)$ \\
$N$ & 1,176 & 1,176 & 1,176 \\
\hline \hline
\end{tabular}

Results from Table A12 suggest that my Muslim representation treatment increased respondents' perception that Muslim healthcare workers are at the forefront of combatting the coronavirus (column 1). In addition, it appears that respondents who were provided additional information regarding the severity of the COVID-19 crises were more likely to evaluate the COVID-19 crisis as 


\section{Please read the following paragraphs carefully:}

In the past weeks, the Coronavirus (COVID-19) has hit many countries, causing serious health and economic consequences. Officials from the CDC and NIH emphasize that COVID-19 poses an unprecedented challenge which will have major detrimental effects on the American people's public health and economy. For that reason, they argue that it is extremely important that health institutions in the U.S. seriously prepare for treating patients with COVID-19, for which a cure has yet to be found.

According to the Center for Disease Control and Prevention (CDC), the virus' main symptoms include:

- Fever

- Cough

- Shortness of breath

Official statistics suggest that there are over a million healthcare workers providing services in hospitals and clinics across the United States. Recent studies show that in many localities across the United States, a sizable proportion of healthcare workers are Muslim. Specifically, over 50,000 doctors and many more nurses working in American hospitals are Muslim. These Muslim healthcare workers are taking care of American citizens in urban as well as rural communities all across the United States.

Indeed, doctors, nurses, paramedics, pharmacists, and other healthcare employees are working around the clock to ensure that the American people will successfully and safely prevail over the Coronavirus.

In recent days, many Congress-members have expressed their gratitude towards healthcare workers in the United States, who are working around the clock in order to provide medical services and care for American patients. They further emphasized that they seek to serve the public, by promoting legislation which will aid the American people.

Over that past several years, American elected officials have supported and promoted policies in different areas, relating to: healthcare reform, international trade, and education policy. /, education policy, and restrictions on immigration from Muslim countries.

Figure A3: Experimental Vignette: $2 \times 2 \times 2$ Design, severity treatment depicted in green, representation treatment depicted in blue, and political exclusion treatment depicted in red. 
more severe in the U.S. (column 2). That said, the null effects in column 3 of Table A12, suggest that my political exclusion statement was ineffective in shaping respondents perspectives regarding the prevalence of preferences for exclusion amongst politicians.

\section{B.2.2 Balance and Robustness Checks}

In Table A13 I report results from simple balance tests, in which I compare the demographics of respondents assigned to my main treatment and control condition relating to Muslim representation. Overall, it appears that respondents' are well balanced across conditions. Regardless, in Figure A4, I demonstrate that my results remain robust when controlling for additional treatment arms and pre-treatment covariates. Lastly, In Figure A5 I consider a placebo test, where I regress attitudes towards a host of social groups (Democrats, Republicans, Muslims, Hispanics, African Americans, and Asian Americans), over my main treatment regarding Muslim representation. Overall, it seems that my treatment mainly impacted prejudice towards Muslims, while not having a consistent and significant effect on prejudice towards other social groups.

Table A13: Balance on Covariates (US Sample)

\begin{tabular}{llrrrrr}
\hline & Variable & N Treatment & N Control & Treatment Mean & Control Mean & p. Value \\
\hline 1 & Age & 612 & 599 & 47.79 & 48.77 & 0.30 \\
2 & Male & 612 & 599 & 0.45 & 0.45 & 0.90 \\
3 & Education & 612 & 599 & 4.48 & 4.61 & 0.23 \\
4 & White & 611 & 599 & 0.76 & 0.73 & 0.23 \\
5 & Ideology & 612 & 599 & 1.97 & 1.92 & 0.53 \\
\hline
\end{tabular}

Lastly, in Table A14, I consider the effects of my main treatment on respondents willingness to abide by public health guidance devised to limit the spread of COVID-19. Specifically, I consider the respondents' likelihood of wearing masks, visiting friends and family, and leaving their home. Results from Table A14 suggest that my treatment does not affect these outcomes. Indeed, even when considering heterogenous treatment effects amongst Republican respondents, I still find no evidence for a negative externality of representation on majority group members' social distancing behavior. 


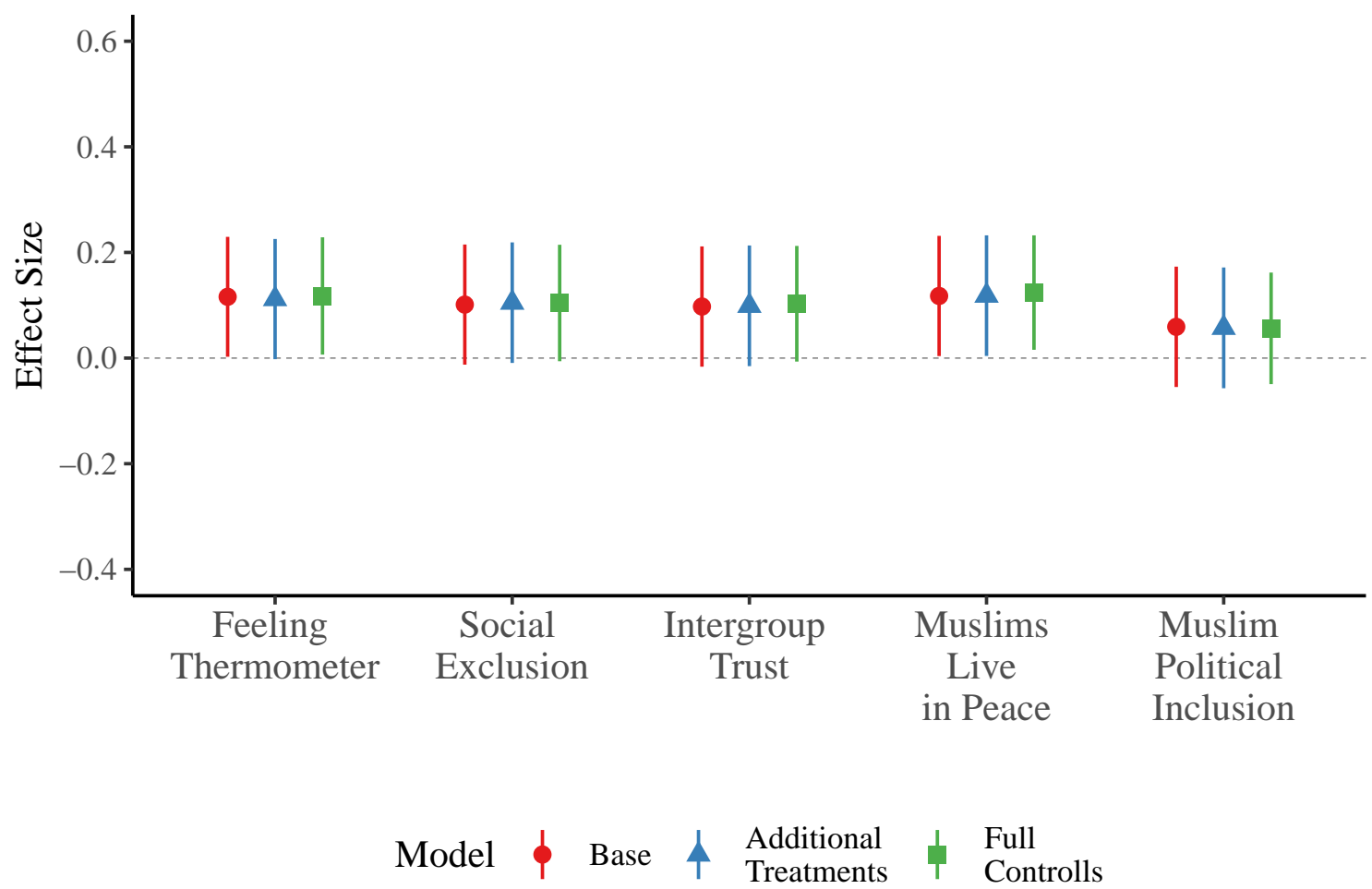

Figure A4: U.S. Experiment Robustness to Alternative Specifications - OLS point estimates and their corresponding confidence intervals represent the average treatment effect of information regarding Muslim representation on prejudice attitudes and preferences for political exclusion. The full control model include the following covariates: age, race, religion, education, and experimental bloc.

Table A14: Effect of Muslim Representation on Social Distancing (US)

\begin{tabular}{lcccccc}
\hline \hline & \multicolumn{2}{c}{ Mask } & \multicolumn{2}{c}{ Visit Friends } & \multicolumn{2}{c}{ Leave Home } \\
& $(1)$ & $(2)$ & $(3)$ & $(4)$ & $(5)$ & $(6)$ \\
\hline Representation & 0.047 & 0.063 & 0.016 & 0.042 & -0.019 & 0.023 \\
& $(0.058)$ & $(0.069)$ & $(0.058)$ & $(0.070)$ & $(0.058)$ & $(0.070)$ \\
Republican & & -0.288 & & -0.086 & & -0.248 \\
& & $(0.117)$ & & $(0.119)$ & & $(0.118)$ \\
Representation*Republican & & 0.014 & & -0.033 & & -0.050 \\
& & $(0.118)$ & & $(0.120)$ & & $(0.120)$ \\
Controls & No & Yes & No & Yes & No & Yes \\
$N$ & 1,202 & 1,201 & 1,202 & 1,201 & 1,202 & 1,201 \\
\hline \hline
\end{tabular}

Notes:

Controls include: age, race, religion, education, block, and indicators for exclusion and severity treatments. 


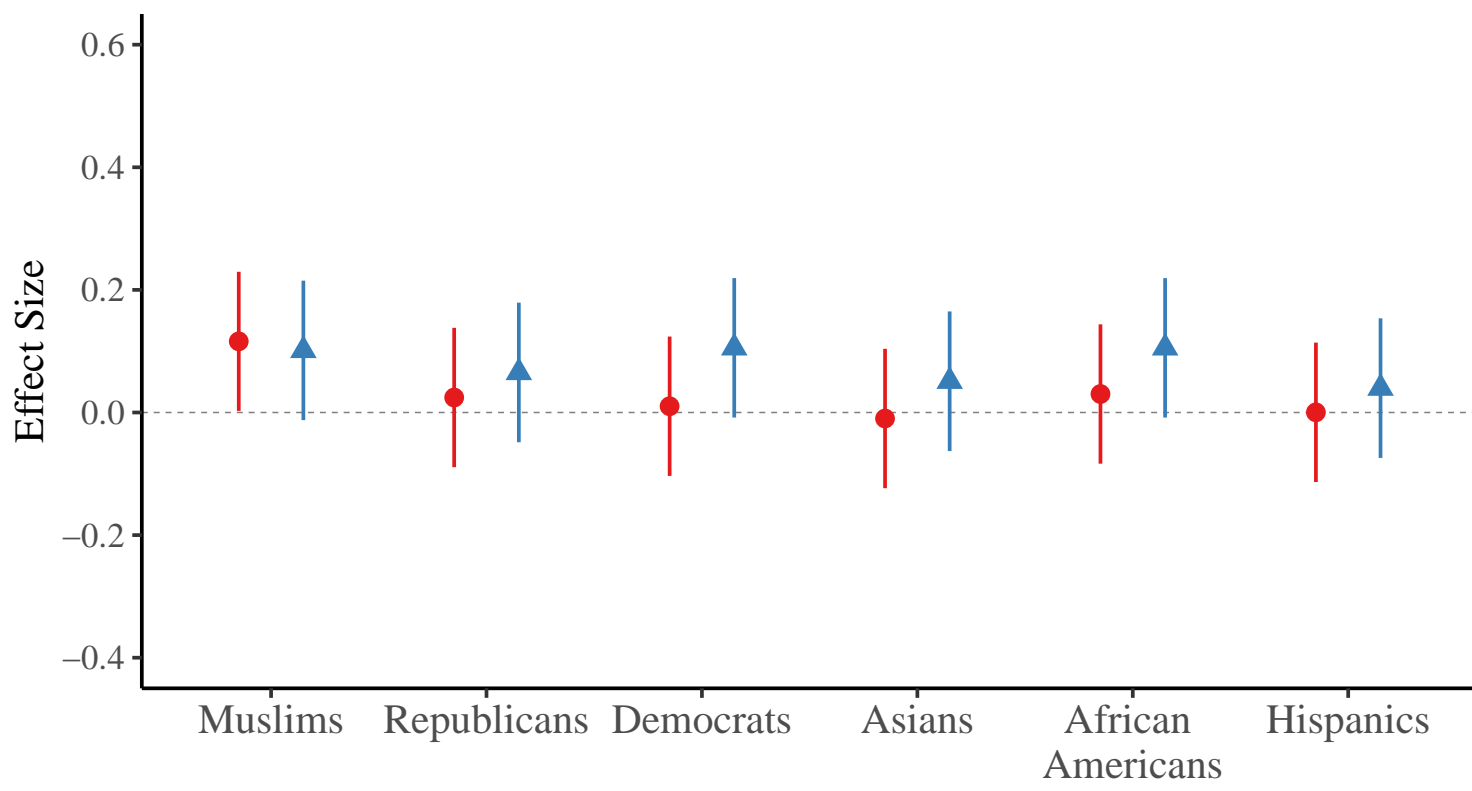

Outcome $\phi$ Feeling $\begin{array}{ll}\text { Social } \\ \text { Thermometer }\end{array}$ Exclusion

Figure A5: Placebo Test - OLS point estimates and their corresponding confidence intervals represent the average treatment effect of information regarding Muslim representation on prejudice attitudes towards Muslims, Republicans, Democrats, Asians, African Americans, and Hispanics

\section{B.2.3 Heterogenous Treatment Effects}

In this section, I report a series of pre-registered heterogenous treatment effects. Despite finding limited support for the moderating effects of crisis severity and politician's preferences for exclusion in the Israeli context, I further consider these moderators in my U.S. experiment. In Tables A15-A16 I consider these possibilities by interacting my representation treatment with a binary variable taking the value of one for respondents primed with the severity or exclusion treatments. As demonstrated in these tables, I find no support for my expectation that the severity of the COVID-19 crisis, or politicians' exclusionary behavior moderates my main average treatment effects. These findings are in line with the null results from my Israeli experiment reported in Tables A4-A5.

I further evaluate the extent to which the perceived severity of COVID-19 impacts reactions to my main treatment (i.e. information regarding Muslim representation) in Tables A17-A18. 
Table A15: Heterogenous Treatment Effect of Muslim Representation Conditional on Severity (US)

\begin{tabular}{lccccc}
\hline \hline & Therm & Soc Exclusion & Trust & Peace & Pol Inc \\
& $(1)$ & $(2)$ & $(3)$ & $(4)$ & $(5)$ \\
\hline Representation & 0.291 & 0.152 & 0.194 & 0.206 & 0.205 \\
& $(0.083)$ & $(0.083)$ & $(0.083)$ & $(0.083)$ & $(0.083)$ \\
Severity & 0.154 & 0.063 & 0.118 & 0.106 & 0.129 \\
& $(0.082)$ & $(0.083)$ & $(0.083)$ & $(0.083)$ & $(0.083)$ \\
Representation*Severity & -0.343 & -0.098 & -0.187 & -0.171 & -0.286 \\
& $(0.115)$ & $(0.116)$ & $(0.116)$ & $(0.116)$ & $(0.116)$ \\
$N$ & 1,193 & 1,188 & 1,186 & 1,186 & 1,186 \\
\hline \hline
\end{tabular}

Table A16: Heterogenous Treatment Effect of Muslim Representation Conditional on Exclusion (US)

\begin{tabular}{lccccc}
\hline \hline & Therm & Soc Exclusion & Trust & Peace & Pol Inc \\
& $(1)$ & $(2)$ & $(3)$ & $(4)$ & $(5)$ \\
\hline Representation & 0.116 & 0.104 & 0.148 & 0.186 & 0.104 \\
Exclusion & $(0.081)$ & $(0.081)$ & $(0.081)$ & $(0.081)$ & $(0.081)$ \\
& -0.058 & 0.050 & 0.064 & 0.071 & 0.024 \\
Representation*Exclusion & $(0.082)$ & $(0.083)$ & $(0.083)$ & $(0.083)$ & $(0.083)$ \\
& -0.007 & 0.002 & -0.102 & -0.139 & -0.094 \\
$N$ & $(0.116)$ & $(0.116)$ & $(0.116)$ & $(0.116)$ & $(0.116)$ \\
\hline \hline
\end{tabular}


Specifically, I leverage a pre-treatment question in which I presented respondents with a series of health conditions, and asked them to select any condition which they have. The conditions I presented to respondents' were those which the CDC has originally identified as conditions which increase peoples' risk to suffer severely from COVID-19. Based on responses to this question, I created a binary variable taking the value of one for any respondent suffering from at least one pre-existing condition. In Table A17, I interact my main treatment with this variable and do not find any support for a moderating effect of medical vulnerability on my main treatment.

Table A17: Heterogenous Treatment Effect of Muslim Representation Conditional on Pre-Existing Condition (US)

\begin{tabular}{lccccc}
\hline \hline & Therm & Social Exclusion & Trust & Peace & Pol Inc \\
& $(1)$ & $(2)$ & $(3)$ & $(4)$ & $(5)$ \\
\hline Representation & 0.083 & 0.053 & 0.123 & 0.119 & 0.047 \\
& $(0.069)$ & $(0.069)$ & $(0.069)$ & $(0.068)$ & $(0.066)$ \\
Medical Condition & -0.115 & -0.138 & 0.001 & -0.051 & 0.032 \\
& $(0.085)$ & $(0.084)$ & $(0.083)$ & $(0.082)$ & $(0.080)$ \\
Representation*Medical Condition & 0.095 & 0.145 & -0.062 & 0.012 & 0.031 \\
& $(0.119)$ & $(0.119)$ & $(0.118)$ & $(0.117)$ & $(0.114)$ \\
Controls & Yes & Yes & Yes & Yes & Yes \\
$N$ & 1,192 & 1,187 & 1,185 & 1,185 & 1,185 \\
\hline \hline
\end{tabular}

Notes:

Controls include: age, race, religion, education, block, and indicators for exclusion and severity treatments.

In Table A18, I consider a similar exercise focusing on the moderating effects of age, or specifically "vulnerable age" on my main treatment. To do so, I interact my treatment with a binary variable taking the value of 1 for respondents which are 65 or older. Results from Table A18 suggest that being in a vulnerable age group does not moderate the average treatment effect of Muslim representation on prejudice.

As reported in Tables 3-4 of the main text, the average treatment effect of Muslim representation is not moderated by partisanship. However, to further consider the possibility that partisanship moderates my main effects, I employ a strong-partisan variable taking the value of one for respondents who strongly identify as Democrats or Republicans. I interact this variable with my main 
Table A18: Heterogenous Treatment Effect of Muslim Representation Conditional on Vulnerable Age (US)

\begin{tabular}{lccccc}
\hline \hline & Therm & Social Exclusion & Trust & Peace & Pol Inc \\
& $(1)$ & $(2)$ & $(3)$ & $(4)$ & $(5)$ \\
\hline Representation & 0.137 & 0.121 & 0.107 & 0.147 & 0.059 \\
& $(0.064)$ & $(0.063)$ & $(0.063)$ & $(0.062)$ & $(0.061)$ \\
$65+$ & 0.143 & 0.094 & 0.097 & 0.191 & 0.048 \\
& $(0.120)$ & $(0.119)$ & $(0.118)$ & $(0.117)$ & $(0.114)$ \\
Representation*65+ & -0.098 & -0.083 & -0.026 & -0.120 & -0.013 \\
& $(0.140)$ & $(0.139)$ & $(0.138)$ & $(0.136)$ & $(0.133)$ \\
Controls & Yes & Yes & Yes & Yes & Yes \\
$N$ & 1,192 & 1,187 & 1,185 & 1,185 & 1,185 \\
\hline \hline
\end{tabular}

treatment, as an alternative approach to identifying the moderating effect of partisanship on my main treatment. Results from Tables A19-A20 are consistent with the patterns reported in the main text. Indeed, it does not appear that strong partisans (either Democrats or Republicans) respond differently to my main treatmnent.

Table A19: Heterogenous Treatment Effect of Muslim Representation Conditional on Party ID Strong Democrats (US)

\begin{tabular}{lccccc}
\hline \hline & Therm & SD & Trust & Peace & Pol Inc \\
& $(1)$ & $(2)$ & $(3)$ & $(4)$ & $(5)$ \\
\hline Representation & 0.081 & 0.091 & 0.102 & 0.149 & 0.016 \\
& $(0.065)$ & $(0.064)$ & $(0.064)$ & $(0.063)$ & $(0.062)$ \\
Strong Democrat & 0.039 & -0.076 & 0.175 & 0.105 & 0.097 \\
& $(0.117)$ & $(0.116)$ & $(0.115)$ & $(0.114)$ & $(0.111)$ \\
Representation*Strong Democrat & 0.151 & 0.057 & -0.002 & -0.108 & 0.165 \\
& $(0.133)$ & $(0.132)$ & $(0.131)$ & $(0.130)$ & $(0.126)$ \\
Controls & Yes & Yes & Yes & Yes & Yes \\
$N$ & 1,192 & 1,187 & 1,185 & 1,185 & 1,185 \\
\hline \hline
\end{tabular}

Notes:

Controls include: age, race, religion, education, block, and indicators for exclusion and severity treatments. 
Table A20: Heterogenous Treatment Effect of Muslim Representation Conditional on Party ID Strong Republicans (US)

\begin{tabular}{lccccc}
\hline \hline & Therm & Soc Exclusion & Trust & Peace & Pol Inc \\
& $(1)$ & $(2)$ & $(3)$ & $(4)$ & $(5)$ \\
\hline Representation & 0.085 & 0.083 & 0.064 & 0.071 & 0.017 \\
& $(0.064)$ & $(0.063)$ & $(0.063)$ & $(0.062)$ & $(0.060)$ \\
Strong Republican & -0.238 & -0.282 & -0.264 & -0.337 & -0.368 \\
& $(0.125)$ & $(0.124)$ & $(0.123)$ & $(0.122)$ & $(0.119)$ \\
Representation*Strong Republican & 0.162 & 0.114 & 0.193 & 0.262 & 0.205 \\
& $(0.137)$ & $(0.136)$ & $(0.135)$ & $(0.134)$ & $(0.130)$ \\
Controls & Yes & Yes & Yes & Yes & Yes \\
& 1,192 & 1,187 & 1,185 & 1,185 & 1,185 \\
\hline \hline \multirow{2}{*}{ Notes: } & \multicolumn{4}{c}{ Controls include: age, race, religion, education, block, } \\
& and indicators for exclusion and severity treatments.
\end{tabular}

